\title{
Sosyo
}

Ekonomi

\section{Ekonomik Krizlerin Değişmeyen İmdatçısı*: Maliye Politikası}

Hüseyin ŞEN
hsen@ybu.edu.tr

Unchanging Rescuer of Economic Crises: Fiscal Policy
Ayşe KAYA

ayse.kaya@ikc.edu.tr

\begin{abstract}
This paper studies the role of fiscal policy, which has recently come to the fore as a rescuer during economic crises and focuses very much on its historical role in economic crises in general and in the recent crisis in particular.
Keywords
: Economic Crisis, Fiscal Policy, Monetary Policy, Macroeconomic Policy.
JEL Classification Codes $\quad$ : $\quad$ H12, E62, E52, E60.

\section{Özet}

$\mathrm{Bu}$ çalışma, her küresel ölçekli ekonomik krizle birlikte imdatçı olarak gündeme gelen maliye politikasını ve bu politikanın krizlerle mücadeledeki rolünü tarihsel bir perspektif çerçevesinde ele alıp; değerlendirmeyi ve ileriye yönelik politika önerileri sunmayı amaçlamaktadır.

Anahtar Sözcükler
: Ekonomik Kriz, Maliye Politikası, Para Politikas1, Makroekonomik Politika. 
Hüseyin ŞEN \& Ayşe KAYA 
"Iktisatta sorular hep aynidır. Değişen bir şey varsa o da cevaplardır."

Anonim

\section{Giriş}

Her ekonomik kriz, kendi çapında bir güçlük, bir sıkıntı demektir. Ama her kriz aynı zamanda ders çıkarmasını bilenler için yeni bir başlangıç, yeni bir firsatlar ve tecrübeler manzumesi de demektir. Biliyoruz ki ekonomik krizler günümüz ekonomilerinin değişmeyen bir gerçeği. Dün vardı, bugün de var, yarın da var olacaklar gibi görünüyor. Ekonomik krizlerle mücadele ve krizlerden çıkış için alınacak tedbirlerin ilk sırasına dün olduğu gibi bugün de maliye politikası oturmuş durumda. Son yaşanan ve hala belli bir ölçüde de olsa etkisini sürdüren küresel ölçekli krizde de durum bundan farklı değil.

2007 yılının ikinci yarısında ABD'de emlak ve finans piyasalarında başlayan kriz, 2008'de başta Lehman Brothers olmak üzere, yatırım bankaları Bear Stearns ve Merrill Lynch; sigorta şirketi American International Group ile Washington Mutual ve Wachovia gibi bankaların iflası ile iyice derinleşti. Finans sektörünü kurtarmak ve böylece krizin üstesinden gelmek isteyen ABD Kongresi, 29 Eylül 2008'de 787 milyar dolarlık bir kurtarma paketini onaylad1. Uygulamaya konulan söz konusu paket, Amerikan tarihinin şimdiye kadar kaydettiği en büyük krizle mücadele paketi olma özelliğini taşıyordu (Romer, 2011).

Kriz sürecinde piyasaların toparlanması için ABD Merkez Bankası -FEDgevşek para politikası adına nicel gevşeme uygulamalarından ${ }^{1}$ kapsamlı nihai ödünç veren mercii olma tedbirlerine kadar elinde ne kadar enstrüman varsa hemen hemen hepsini denedi. ${ }^{2}$ Ancak alınan bütün önlemlere rağmen, krizin derinleşmesinin ve yayılmasının önüne geçilemedi ve kriz sirayet etkisi ile hızla ABD’yi aşıp; Avrupa'ya ve oradan da dünyanın diğer ülkelerine sıçradı. Bu sıçramada, FED'in her türlü parasal enstrümanı devreye sokarken, diğer riskli ülkelerin büyük çoğunluğunun aynı hassasiyeti göstermemeleri ve krize karşı yeterli önlemleri almamaları önemli ölçüde etkili oldu. Bu süreçte kısmen Fransa, Almanya, Çin gibi ülkeler bazı ekonomik-mali önlemler alsalar da krizin üstesinden gelmede bu önlemler yeterli olmadı.

1 “Quantitative easing” karşıllğ̆ olarak kullanılmıştır. Türkçe literatürde daha çok “parasal gevşeme” olarak kullanılsa da, TCMB resmi sitesinde bu kavram "Nicel gevşeme uygulamalart” şeklinde telaffuz edilmektedir. $O$ nedenle Türkiye'de parasal otorite olan TCMB'nin telaffuzu dikkate alınmıştır.

2 Son krizde para politikası ve para politikasına ilişkin çıkarllacak dersler konusunda bkz. Jordan (2012). 
Zamanında gerekli önlemleri almayan Yunanistan, İspanya, Portekiz, İtalya, İrlanda ve Belçika gibi Avrupa Birliği ülkeleri ile yine bir Avrupa ülkesi olan ancak birlik dışındaki İzlanda, krizden ziyadesiyle etkilendi. Üç büyük bankası ${ }^{3}$ iflas eden ve ekonomik göstergeleri ${ }^{4}$ alt üst olan İzlanda, küresel ekonomik krizin en büyük mağduru oldu ve adı "batan ülke" olarak anılmaya başlandı. Değindiğimiz bu ülkeler İzlanda kadar olmasa da, kendilerini ciddi bir borç sorunu içinde buldular. Öte yandan, Avrupa'nın en istikrarlı ülkelerinden biri olarak kabul edilen ve "güneş batmayan imparatorluk" olarak hafizalarda yer edinmiş olan İngiltere de krizden ciddi ölçüde etkilendi ve ABD'de olduğu gibi bu ülkede de emlak piyasası büyük bir düşüşe geçti. Dahası, kriz sürecinde ekonomi literatürüne İngiltere kaynaklı yeni bir kavram girdi: "Çift dipli resesyon",5 2012 y1lına gelindiğinde bu ülkenin GSYİH'si özellikle inşaat sektöründeki daralma nedeniyle birbirini izleyen iki dönemde küçüldü. ${ }^{6}$ İngiltere, çift dipli resesyonla 1970’lerden bu yana ilk kez karşılaşıyordu. O kadar ki, tüm bu gelişmeler üzerine uluslararası arenada "Imparatorluk batıyor mu?" fisıltıları kulaktan kulağa yayılmaya başladı. İngiltere dışındaki diğer ülkeler de, farklı ölçülerde de olsa krizden etkilendi. Krizle beraber birçok finansal kurum ya battı ya da devletleştirilmek zorunda kalındı.

Şüphesiz dünya ekonomileri, 1800'lü yıllardan bu yana irili ufaklı pek çok krize şahit oldu. 1825, 1836, 1847, 1857, 1866, 1873, 1882, 1890, 1900, 1907, 1913, 1920, 1929-1933, 1973, 1997-1998, 2008-2009 yıllarında veya dönemlerinde yaşananlar bizim hatırlayabildiğimiz krizlerden bazılarıdır. ${ }^{7} \mathrm{Bu}$ krizlerin en şiddetlisi şüphesiz iktisat tarihinin şimdiye kadar kaydettiği en büyük kriz olma unvanını hala koruyan ve tarihe “Kara Perşembe" olarak giren 24 Ekim 1929 Buhranı'dır. ${ }^{8}$

New York Borsası'nın çökmesi ile başlayan, hızla Avrupa'yı etkisi altına alan ve oradan da hemen hemen dünyanın bütün ülkelerine sirayet ederek küresel bir boyut kazanan buhran; üretimde, istihdamda ve milli gelirde daha önce eşine benzerine hiç

3 Bu bankalar Glitnir, Landsbanki ve Kaupthing 'dir.

42008 ve 2009 ylllar İzlanda için krizin zirve yaptı̆̆ yıllardl. IMF verilerine göre, 2007 yılında \%6 olan büyüme orant, 2008'de \%1,3; 2009'da \%-6,8; 2010 yılında da \%-4,0 olarak gerçekleşti. 2007 yllında \%9,3 olan nominal ücret endeksi, 2008 yılında \%4,0, 2009 yılında da \%0,5 olarak gerçekleşti. Benzer şekilde, 2007 yılında \%5,0 olarak gerçekleşen tüketici fiyatları endeksi, 2009 yllında \%12,4'e firladı. Benzer negatif gelişmeleri, ülkenin diğer temel göstergelerinde de görmek mümkündür. Ayrıntılı veriler için bkz. IMF Staff Country Report:12/91, April 2012.

5 Bir ülke ekonomisinin resesyondan çıkışa geçtikten sonra, tekrar küçülmeye başlaması, çift dipli resesyon veya diğer adıyla "W tipi resesyon" olarak adlandırlmaktadır.

6 OECD verilerine göre Ingiltere'nin 2012 yılı büyüme rakamları çeyreklik bazda şu şekilde gerçekleşti: Ç1:\%0,01, Ç2:\%-0,02, Ç3:0,08 ve Ç4:\%-0,03. Bkz. http://stats.oecd.org/index.aspx?queryid=350\#[Erişim tarihi: 1.10.2014].

7 Tarihsel süreçte yaşanan krizler için bkz. Kindleberger (2007), Aktan \& Şen (2001), Şen \& Çalişkan (2009).

8 Literatürde 1929 Buhranı'nın ne zaman çıktı̆̆ konusunda iki farklı tarih mevcuttur: 24 Ekim 1929 Perşembe ve 29 Ekim 1929 Sall. Bu çalışmada Buhranı'nın borsa üzerinde ilk etkisini gösterdiği 24 Ekim 1929 tarihini başlangıç tarihi olarak dikkate alınmıştır. 1929 Buhranı öncesi ve sonrasındaki gelişmelere ilişkin olarak bkz. White (1990). 
rastlanmamış derecede düşüşlere neden oldu. Dahası, akut deflasyonu da beraberinde getirdi ve insanların yaşam standartları aşırı ölçüde kötüleşti. 1929 Buhranı'nın işsizler ve aileler üzerindeki etkisini Peter Temin'in şu ifadeleri başka söze yer bırakmayacak şekilde özetliyor:

"1930’larda özellikle Avrupa ve ABD için işsizlik demek, acı ve ıstırap demekti. Bazı bölgelerde evde yetiştirilen sebzelerin varliğına ră̆men, Avrupa'da zorunlu olarak diyet yapmak çok sıradan bir hale gelmişti. Aileler nadiren et yiyebiliyordu, temel besin kaynağı nişasta idi. Şeker yerine daha ucuz tatllar ikame ediliyordu. Bu kötü beslenme bile hemen hemen bütün ailelerinin gelir kaynaklarının tükenmesine neden oldu. Çocuklu aileler süt, çoğu da isınmak için kömür satın aldığından, ayakkabı ve diğer harcamalar için çok az para kalıyordu. Ayakkabı işi özellikle ciddi bir sorundu. Ailelerin eskimiş ayakkabılarını değiştirmeye bile güçleri yetmiyordu. Ayakkabılar yamanıyordu ve bir daha yamanıyordu. Bazı aileler çocukların ayakkabılarını aşındırmasına ve yıpratmasına bile kisıtlama getirmişti. Harcamalar gida maddelerine, özellikle de ekmek ve kahveye tahsis edildiğinden, kasaba ve köylere seyahat bile azalmıştı." (Temin, 2008: 5493-5494).

Krizin zamanlaması ve şiddeti ülkeler arasında önemli farklılıklar gösterse de (Romer, 2003), en şiddetli biçimde etkisini gösterdiği 1929-1932 yılları arasında sanayi üretimi ABD'de \%53,8; Almanya'da \%53,3; İngiltere'de \%83,5; Fransa'da \%71,6 oranında düştü. Öte yandan işsiz sayısı ABD'de 12; Almanya'da 6, İngiltere'de de 2,6 milyona ulaştı. Toptan eşya fiyat endeksi, ABD'de \%31,2; Almanya'da \%30; İngiltere'de \%33 oranında düştü ki, fiyatlar genel düzeyindeki bu denli yüksek orandaki düşüşler "deflasyon" dan başka bir şey değildi. Tüm bunların etkisi ile de bahse konu olan dönemde dünya ticareti hacimsel olarak \%33, değer bazında da \%67 oranında geriledi. ${ }^{9}$ Dahası, buhranın sosyal ve kültürel etkileri de ekonomik etkilerinden hiç de aşağı değildi. Özellikle ABD için kriz, öylesine bir etkide bulundu ki Amerikan tarihinde en ölümcül kriz olan Amerikan İç Savaşı'ndan sonra ikinci sırayı aldı (Romer, 2003).

ABD'de 2007 yılının ikinci çeyreğinde başlayan son kriz de, yukarıda sıraladığımız krizlerden sadece biri. Ancak son krizi diğerlerinden farklı ve önemli kılan şey sürekli olarak 1929 Buhran'1 ile ilişkilendirilmesi veya bir benzeri imasında bulunulması ve bazı ekonomistler tarafindan da bunun açıkça dillendirilmesidir. $\mathrm{Bu}$ minvalde 2008'de başlayan ve hızla küresel bir boyut kazanan kriz, oldukça geniş yelpazedeki akademik ve akademik olmayan kesim tarafindan 1929 Buhranı'ndan sonraki en büyük ve en uzun süren kriz olarak kabul edilmeye başland $1^{10}$ ve o noktaya gelindi ki;

9 Veriler tarafimızca farklı kaynaklardan seçilerek derlenmiştir.

10 Bkz. örneğin, Claessens, Kose \& Terrones (2008), Spilimbergo, Symansky, Blanchard \& Cottarelli (2009), Alcidi \& Gros (2011). 
kriz, "great recession" veya "global recession"11,12,13 olarak adlandırıldı. Çünkü ABD'de emlak ve finans piyasalarında başlayan kriz, 1929 Buhranı'nda olduğu gibi hem gelişmiş, hem de gelişmekte olan ülkeleri etkiledi. Kriz kısa zamanda bir likidite ve güven krizine dönüştü ve yatırımların azalmasına, piyasalarda güven kaybına neden oldu. En nihayetinde de reel sektörü etkisi altına aldı. Bu durum yatırım, üretim ve tüketim seviyesinin gerilemesine, ekonomik büyümenin yavaşlamasına ve milyonlarca insanın işsiz kalmasına neden oldu. Doğal olarak bu da ülke hükümetlerinde ve piyasalarda bir panik havasının yaşanmasına yol açtı. Krize genelde, Neo-liberal politikaların yönlendirmesi ile 1980 sonrası süreçte dominant olan ve hatta yegâne iktisat politikası aracı haline gelen para politikası; özelde ise bu politikanın temel enstrümanı olan faiz oranı ile müdahale edilmesine karşın, olumlu bir sonuç alınamadı. Para politikası nominal faiz oranlarının sıfira dayanması nedeniyle krizle mücadelede bir işlevsellik gösteremedi.

Daha önceki krizlerde olduğu gibi, son yaşanan Global Ekonomik Kriz de bir kez daha maliye politikasını gündeme getirdi. Para politikasından beklenen sonucun alınamadığı bir ortamda acaba krizle birlikte ortaya çıkan varlık fiyatlarındaki düşüşe, kaybolan güvenin yeniden tesisine, artan kredi ve hammadde fiyatlarına ve bütün bunların bir sonucu olarak ortaya çıkan resesyon ve ekonomik durgunluğa karşı ihtiyari-aktif bir maliye politikası sonuç verir miydi?

$\mathrm{Bu}$ çalışmanın amacı, tarihsel perspektiften maliye politikasının ekonomik krizlerdeki rolünü geçmişin deneyimlerini de bugüne aktarmak suretiyle değerlendirmek, maliye politikasının makroekonomik yönetimdeki rolü konusunda yakın geleceğe ilişkin bir perspektif çizmektir. Beş bölümden oluşan çalışmanın ikinci bölümünde maliye politikasının tarihsel açıdan gelişimi ele alınırken, üçüncü bölümde son yaşanan ekonomik krizle birlikte maliye politikasına bakıştaki değişim ve dönüşüm üzerinde durulmaktadır. Dördüncü bölümde de bu hususta gelinen nokta irdelenmektedir. Çalışmanın son bölümünde ise sonuç ve ileriye dönük politika çıkarımlarına yer verilmektedir.

11 Bu konudaki çok sayıda çalsşma arasında bkz. örneğin; Pelinescu \& Caraiani (2010), Auerbach, Gale \& Harris (2010), Barro \& Redlick (2011), Tcherneva (2011), Alcidi \& Gros (2011), Alesina (2012), Coenen, Straub \& Trabandt (2012), Arestis (2012a), Arestis (2012b), Auerbach (2012).

12 Resesyonun ne olduğu ve depresyonla aralarnnda ne gibi bir fark olduğu konusunda resmi bir tanım ve akademisyenler arasında da tam bir uzlaşı olmamakla birlikte; resesyon, bir ekonomide birbirini izleyen en az iki çeyrekte ekonomik büyümenin sıfir ya da negatif olması halidir. Resesyonun 1-2 yll veya daha uzun süreyi aşkın devam etmesi durgunluk olarak adlandirlmaktadır. Depresyon ise ekonomik büyümedeki gerilemenin daha şiddetli, derin ve uzun bir zaman dilimini kapsaması halidir. Yani, fiyatlar genel düzeyindeki düşüşle beraber ekonomik büyümenin tamamen dibe vurması durumudur. Kaba bir oran vermek gerekirse, GSYIH'nn \%10'dan, fiyatlar genel düzeyinin ise $\% 20$ 'dan daha fazla bir oranda düşmesi deflasyonun göstergeleridir.

13 Resesyon ve deflasyonun farklı tanımları ve bu konudaki tartışmalar için bkz. örneğin; Bernanke (2002), Claessens, Kose \& Terrones (2008), Claessens \& Kose (2009). 


\section{Ekonomik Krizlerin İmdatçısının Kısa Tarihi: Dünden Bugüne Maliye Politikası}

Kavramsal olarak "maliye politikası" ilk kez Edwin R. A. Seligman [1861-1939] ${ }^{14}$ tarafından 19. yüzyılın başlarında Aldoph Wagner'in hükümetlerin bütçe yoluyla gelir dağılımını düzenlemeleri gerektiği yönündeki görüşünü eleştirmek amacıyla kullanılmıştır (Tanzi, 2006). Orijini Latince bir kelime olan ve "para toplamada kullanılan sepet" anlamına gelen "fiscalis" sözcüğüne dayanan maliye politikası, J. M. Keynes'e kadar, genelde kamu gelirlerine, özelde de vergilere ilişkin politika anlamında kullanılmıştır.

Ancak Keynes ile maliye politikasına farklı bir anlam yüklenmiş; maliye politikası bütçenin yalnızca gelir cephesiyle ilgilenen bir politika olmaktan çıkmış, gelir ve harcama yönlerinin her ikisini de kapsar hale gelmiştir (Tanzi, 2006). Dahası, Keynes'le birlikte maliye politikası, vergiler ve kamu harcamaları yoluyla ekonomiyi tanzim eden, ekonomiye yön veren yegâne iktisat politikası aracı haline gelmiştir. Diğer bir iktisat politikası aracı olan para politikası ise maliye politikasına eşdeğer bir politika aracı olmaktan daha ziyade, adeta bu politikanın stepnesi durumuna düşmüştür.

Klasiklerin söylemlerinin aksine, ekonominin sürekli tam istihdamda olmadığını; tam istihdamın istisnai bir durum olduğunu savunan Keynes, devlet müdahalesi olmadan ekonomilerin neden tam istihdam düzeyinde kendiliğinden dengeye gelmeyeceğini şu üç gerekçeye dayanarak açıklamıştır: Likidite tuzağının varlığı, yatırım-tasarruf tutarsızlığı ve ücretlerin rijitliği. Keynes'e göre, söz konusu faktörler ekonominin tam istihdam düzeyinde dengeye gelmesini engeller. O nedenle 1929 Buhranı sonrasındaki sürecin de kanıtladığı gibi, ekonomiler için konjonktürel dalgalanmalara bağlı olarak dönem dönem ortaya çıkacak talep yetersizliği bir realitedir.

Keynes'e göre, efektif talep yetersizliği zaten özel kesimin tüketim ve yatırım harcamalarındaki yetersizlikten kaynaklanmıştır. O halde yapılması gereken devlet müdahalesi ile bu yetersizliğin üstesinden gelmektir. Efektif talebin unsurlarını sıralayan Keynes, bunu etkileyecek yegâne aracın maliye politikası olduğu noktasından hareketle, efektif talep yetersizliğinin genelde genişletici maliye politikası ile özelde de genişletici kamu harcamaları politikası yoluyla aşılması ve böylece hem ekonomilerin tam istihdam düzeyinde dengeye getirilmesi, hem de gayri iradi işsizliğin önüne geçilmesi gerektiğini savunmuştur.

14 Colombia Üniversitesi iktisat profesörlerinden olan Seligman, yaşadığı dönemde daha çok vergileme ve kamu maliyesi alanındaki çalışmalar ile isim yapmış bir akademisyendir. 
Biraz önce de değindiğimiz gibi, 1929 Buhranı'nın nedenini ${ }^{15}$ efektif talep $^{16}$ yetersizliğinde gören Keynes, çözümü de efektif talebi etkileme potansiyeline sahip bir iktisat politikası aracı olarak kabul ettiği maliye politikasında görmüştür. Maliye politikasına bu hususta yeni bir anlam ve misyon yükleyen Keynes, bu politikayı "efektif talebi etkilemek için vergiler ve kamu harcamalarının miktar ve bileşiminde yapılan ayarlamalar" olarak ele almıştır.

Keynes'in teorik söylemleri, ABD'de Mart 1933'de işbaşına gelen Franklin D. Roosevelt'in uygulamaları ile pratiğe dönüştürülmeye başlanmıştır. Daha iktidarının baharında işsizliğin $\% 25^{\prime}$ lere çıktığı, reel üretimin $\% 30$ oranında düştüğ ${ }^{17}$, dibe vuran bir ABD ekonomisi ile yüzleşmek zorunda kalan Roosevelt, ilk icraatına mali, ekonomik ve sosyal önlemler paketini içeren iki aşamalı New Deal'i uygulamaya koyarak başladı. Birinci aşama 1933-1934, ikinci aşama ise 1935-1938 dönemlerini kapsiyordu. Birinci aşamada bankacılık, tarım ve kırsal kalkınma ve sanayiye kadarki farklı kesimlerin ekonomik açıdan varlıklarını sürdürmesini sağlama üzerine odaklanılmış iken, ikinci aşamada daha çok mevzuata yönelik düzenlemeler üzerine odaklanılmıştır.

Türkçe karşılığı olarak "Yeni eylem planı" şeklinde ifade edebileceğimiz söz konusu plan, aslında krizden çıkabilmek için uygulamaya konulan genişletici maliye politikası önlemlerinden başka bir şey değildi. Açıkça ifade edilmese de, özünü J. M. Keynes'in fikirlerinin oluşturduğu plan, devletin ekonomiye oldukça kapsamlı müdahalesini öngörüyordu. Kısaca, “ $3 R$ ” ile sembolize edilen plan şu üç konuyu ihtiva ediyordu: Yardım [Relief], İyileşme [Recovery], ve Reform [Reform]. Burada yardımdan kasit, işsiz ve fakirlere devletçe destekte bulunulması; iyileşmeden kasit, ABD ekonomisinin düzlüğe çıkartılması; reformdan kasıt da, finansal sistemin olası artçıl deflasyon şoklarından korunmasıdır.

15 Bugün bile 1929 Buhranı'nın nedenleri konusunda akademisyenler arasında bir uzlaşı yoktur. Örneğin Adam Smith 'in öncülüğünde gelişen Klasik yaklaşım buhranı reel ücretlerin yüksekliğine, Milton Friedman öncülüğ̈̈nde gelişen Monetarist yaklaşım, FED'in uyguladığl yanlış para politikalarına bağlarken; J. M. Keynes öncülüğ̈̈ndeki Keynesyen yaklaşım, krizin nedenini efektif talep yetersizliğinde görmektedir. Bununla beraber buhranın nedenlerinin çok çeşitli olduğu noktasından hareketle, buhrana ilişkin şu nedenleri sıralayabiliriz: Zayıf ve spekülatif kredi yapısının 1929 hisse senedi borsasındaki düşüşle birlikte çökmesi, yanlış uygulanan para politikası, teknolojinin neden olduğu işsizliğin giderek yaygınlaşması, bozulan gelir dağılımı, tarım sektöründe çalışanların satınalma güçlerindeki düşüş, yatırımlardaki düşüşün milli gelirdeki düşüşü beraberinde getirmesi, olumsuz çarpan etkisi ve tüm bunların etkisiyle de sermaye birikimindeki düşüş gibi oldukça çeşitli ve birikmiş sorunların yattı̆̆ını söylemekle hata yapmış sayılmayız.

16 Fiili satınalma gücü ile desteklenen talep demektir. Dlşa kapalı ve devlet müdahalesinin olmadığl bir ekonomide efektif talep, özel kesim tüketim ve yatırım harcamalarının toplamına eşittir. Yani, $Y=C+I$ 'dir. Devlet müdahalesinin olduğu dişa açık bir ekonomide ise efektif talep, $Y=C+I+G+X-M$ şeklinde olacaktır. Burada; C: otonom tüketimi, I: otonom yatırımı, G: otonom kamu harcamalartni, $X-M$ ise net ihracat göstermektedir.

17 Veriler Wheelook'a (1992:4) aittir. 
Ulusal ve federal düzeyde sosyal refah programlarının hayata geçirilmesi, sanayi kuruluşlarının regüle edilmesi, konut ve mevduat sigortaları ve işgücü politikaları (Fishback, 2008) yukarıda sıraladığımız " $3 R$ " için izlenecek politikalardan sadece birkaçıydı. New Deal Planı eksenli bu müdahalenin iki önemli ayağından birini, devletin büyük yatırım projelerine girişmesi, diğerini ise kamu harcamaları yoluyla Amerikan vatandaşlarının alım güçlerinin arttırılması oluşturuyordu. $\mathrm{Bu}$ çerçevede eyalet ve yerel hükümetlerle eşgüdüm halinde acil kamu istihdam politikalarının hayata geçirilmesi ve yol, baraj, köprü, toplu konut, sıhhi tesis, okul yapımı gibi kamu alt yapı yatırımları ön plana çıkarılarak ve inşasına girişilerek işsiz olan milyonlara istihdam olanağı yaratılması amaçlanıyordu.

Keynes'in söylemleri ve Roosevelt'in uygulamaları ile şekillenen tüm bu politikalar, 1930'lu yıllarda emme-basma su tulumbasindan hareketle, "pump-priming policy" olarak maliye-iktisat literatürüne girdi. ${ }^{18}$ Tulumbayı suya alıştırmak için "tulumbaya konan ilk su" anlamina gelen pump-priming kavramı, mali anlamda "ekonomik durgunluğun telafi edici kamu harcamaları yoluyla aşılması" demektir. Bunun altında yatan mantık şuydu: İlave kamu harcamaları yoluyla ekonomiye yeteri kadar kaynak aktarılması durumunda müteşebbislerin geleceğe ilişkin bakış açıları değişecek ve ülke ekonomisi bundan olumlu yönde etkilenecek ve sonuçta da ekonomi durgunluktan çıkıp konjonktürün canlanma safhasına girecekti. Bu da bir ekonomide tüketim ve yatırım harcamalarının artması ile ekonomide çarpan ve hızlandıran prensiplerinin harekete geçmesi demekti. Beklenti oydu ki hem milli gelir düzeyi yükselecek, hem de işsizlik azalacaktı. Roosevelt yönetimi, özellikle işsizliğin daha yüksek, gelirdeki azalışın fazla olduğu alanlara yönelik daha fazla harcama yapma üzerine odaklandı (Fishback, 2008). Amaç bir yandan işsizliğin azaltılması ve bireylerinin alım gücünün arttırılması iken, diğer yandan da telafi edici kamu harcamaları yoluyla, efektif talebin uyarılması ve bunun da müteşebbisler üzerinden özel kesim tüketim ve yatırım harcamaları ile teşvikiydi. Beklenti o yönde idi ki, artan tüketim ve yatırım harcamaları ile hızlandıran ve çarpan mekanizmaları harekete geçecek; böylece ekonominin hem istihdam, hem de milli gelir düzeyi yükselecek ve sonuçta da deflasyon sarmalından çıkılabilecekti.

1929-1933 dönemi kadar olmasa da, Buhran'ın etkisinin devam ettiği bir dönemde, 1936 yılında, Keynes'in “Ístihdam, Faiz ve Paranın Genel Teorisi” başlıklı eseri yayımlandı. 1929 Buhranı'nı bizzat tecrübe etmiş olan Keynes söz konusu çalışmasında hem krizin nedenlerini, hem de krizden çıkışın teorik altyapını sunuyordu. Bu bağlamda da odaklandığı noktalardan biri, toplam talebin ekonominin reel çıktı düzeyi ile istihdamı nasıl etkileyeceğinin teorik açıklamasıydı. Söz konusu şaheser, Keynes'in yalnızca Klasiklerin "bırakınız yapsinlar, bırakınız geçsinler" felsefesini sona erdiren adam değil;

18 Pump-priming policy ile ilgili tartışmalar için bkz. Anderson (1944). 
aynı zamanda "Buhran'ın neden olduğu sorunlara çözüm üreten adam" olarak kısa sürede dünya çapında tanınmasına neden oldu.

Adı açıkça telaffuz edilmese de, ABD'de Roosevelt döneminde "pump priming" ile başlatılan Keynesçi uygulamalar ${ }^{19}$, kısa sürede $\mathrm{ABD}$ ekonomisi üzerinde olumlu etkisini gösterdi ve 1933 yılının ilk çeyreğinden itibaren krizin etkisi yavaş yavaş azalmaya başladı. İşsizliğin azaltılması noktasında istenilen düzeye ulaşılmasa da, diğer makroekonomik göstergelerde kayda değer bir performans yakalandı. Romer'in (2003) tespitlerine göre, 1933-1937 yılları arasında ABD'nin reel GSYIH'sı ortalama olarak \%9 oranında arttı. Dünya ekonomilerindeki iyileşme ülkeden ülkeye farklılık göstermekle birlikte, özellikle 1933 yılı ve sonrasında İngiltere, Almanya, Japonya ve Latin Amerikan ülkelerine kadar, Fransa dışında, tüm ülkelerde benzer olumlu gelişmeler yaşandı. Dünya ekonomilerindeki bu olumlu gelişmeler, Keynes'in "Büyük Buhran'dan çıkışın mimarı" olarak tanınmasını sağlamakla kalmadı, aynı zamanda ekonomide devlet müdahaleciliğinin önünü açtı. O kadar ki, New Deal ile ABD'de devletin manevra alanı o kadar genişledi ki bu genişleme İkinci Dünya Savaşı'ndan bu yana en büyük düzeyine ulaştı (Fishback, 2008).

ABD'deki bu gelişmeler başta Batı Avrupa ülkeleri olmak üzere, diğer ülkeleri de etkiledi. Ne var ki; 1933 sonrası dönemde, kamu harcamalarının arttırılmasına dayalı politikalar, 1929 Buhranı'nın ortaya çıkardığı sorunları bir dereceye kadar çözüme ulaştırabilmişti. 1929-1933 dönemine göre ciddi bir azalma olsa da, işsizlik hala çok ciddi bir sorundu. İşsizlik, 1930'lar boyunca pek çok ülke için yüksek seviyelerde kalmaya devam etti (Temin, 2008). Öte yandan, 1939'da başlayan ve altı yıl gibi uzun bir süre devam eden İkinci Dünya Savaşı, beraberinde adeta bir yıkım getirmiş; kimilerine göre 50 milyon, kimilerine göre 100 milyona yakın kişi savaşta hayatını kaybetmişti. Bunun yanında doğal olarak savaşın etkisi ile mali, iktisadi ve sosyal sorunlar da devasa boyutlara ulaşmıştı. Savaş sonrasında işsizlik artmış, gelir dağılımı bozulmuş, enflasyon yükselmişti. Tüm bu sorunların üstesinden gelmede kamu harcamalarını arttırmaya dayalı Keynesyen maliye politikası yetersiz kaldı. Bunun üzerine, İkinci Dünya Savaşı'nın neden olduğu ekonomik ve sosyal çöküntünün yol açtığı sorunlara çözüm bulmak amacıyla, maliye politikasının amaçlarının yeniden kurgulanması yönünde batılı ülkelerde bir uzlaşı ortamı

19 Pek çok akademisyen [Örneğin; Romer (2003), Fishback (2008)] pump priming policy'nin uygulandiğ dönemde bütçe açılklarında bir artı̧ olmadığını ve vergi gelirlerinin arttı̆ını dayanak göstererek, bunu Keynes'e maletmeme eğiliminde olsa da, bize göre Başkan Roosevelt'in Keynes'in söylemlerinden etkilendiğinden şüphe yoktur. Bunun en somut delillerinden birisi, Roosevelt'in Keynes'in konuşmalarin bizzat kendisinin takip etmesi veya danışmalarına takip ettirmesi, mentalite olarak o zamana kadarki hâkim olan iktisadi görüsse -ki bu Klasik iktisadi düşüncedir.- aykar bir biçimde kamu harcamalartn devreye sokması ve Keynes'in kendisine yazdı̆̆ı mektupları dikkate almasıdır. Örneğin, Keynes'in Roosevelt'e yazdığ 16 Arallk 1933 tarihli mektubu görmek için bkz. http://newdeal.feri.org/misc/keynes2.htm (Erişim Tarihi: 22.10.2014). 
doğdu. Bu uzlaşı, Abba Lerner'in öncülüğünde geliştirilen fonksiyonel [dinamik] maliye yaklaşımında vücut buldu. ${ }^{20}$

Abba Lerner $(1941,1943)$ ortaya attığ fonksiyonel maliye yaklaşımı $1^{21}$ ile Keynes'in müdahaleci politikalarını bir adım daha ileriye taşıdı. Devlete ekonomide daha aktif bir misyon yükleyen bu yaklaşım, tam istihdamın sağlanmasını, fiyat istikrarını ve daha iyi bir yaşam standardının sağlanmasını devletin temel makroekonomik görevleri arasında sayıyor; ekonomide devletin asli görevinin "tam istihdamın sağlanması" olduğu tezinden hareket ediyordu. Klasiklerin tarafsız maliye yaklaşımını tamamen reddeden Abba Lerner'in fonksiyonel maliye yaklaşımı, devlet bütçesinin hazırlanmasında ekonominin içinde bulunduğu durumun gözetilmesi ve bu bağlamda milli gelir-istihdam düzeyi, fiyat istikrarı-büyüme hızı bağlantılarının bütçe hazırlanırken mutlaka dikkate alınması gerektiğini öngörüyordu. $\mathrm{Bu}$ yaklaşım, enflasyonist dönemlerde kamu harcamalarının azaltılıp, vergilerin artırılması suretiyle bütçe fazlası oluşturulmasına, deflasyonist dönemlerde ise bunun tersine bir uygulama ile bütçe açılarına yer verilmesine dayanıyordu. Nihai amaç her ne suretle olursa olsun maliye politikalarının tam istihdamı sağlayacak şekilde dizayn edilmesiydi. dayaniyordu: ${ }^{22}$

Lerner'in tam istihdamı önceleyen fonksiyonel maliye yaklaşımı şu üç kurala

- Devlet, her zaman toplam talebin makul bir seviyede tutulmasını garanti edecektir. Toplam harcamalar çok yetersiz kalmış ve dolayısıyla işsizlik aşırı artmış ise, devlet vergileri azaltacak veya kamu harcamalarını arttıracaktır. Toplam harcamaların aşırı artması söz konusu olduğunda da, kamu harcamalarını kısarak veya vergileri arttırarak enflasyonu önleyecektir.

- Devlet, faiz oranlarını yükseltmek istediğinde borçlanmak; düşürmek istediğinde de, borç vermek veya kamu borçlarını geri ödemek suretiyle, yatırımların optimum miktarını sağlayacak faiz oranını muhafaza edecektir.

- Devlet yukarıda belirtilen ilk iki kuralın bütçe denkliğinin sağlanması, kamu borcunun sınırlandırılması gibi sağlam kamu maliyesi prensipleri ile çelişmesi halinde, karşılıksız para basımı yoluna gidecektir.

20 Bkz. Lerner (1941, 1943).

21 Literatürde devletin iktisadi alandaki asli görevinin "tam istihdamin sağlanması" olduğunu savunan, Klasiklerin tarafsız maliye yaklaşımını reddeden; buna karşın, Keynes'in argümanlarını daha da ileriye taşıyan bir yaklaşımdır.

22 Bkz. Lerner (1941). 
Öte yandan, Lerner'in fonksiyonel maliye yaklaşımı, yukarıda sıraladığımız kurallar çerçevesinde kamu kaynaklarının şu üç fonksiyonu gerçekleştirmek üzere tahsis edilmesini öngörüyordu:

- Kaynak dağılımında etkinlik,

- Gelir dağılımında adalet,

- Makroekonomik istikrar.

Devlete biçilen tüm bu fonksiyonlar Richard A. Musgrave'in 1959 yllında yayımlanan "Kaти Maliyesi Teorisi" 23 adlı eserinde sistemli bir biçimde formüle edilmişti. Musgrave'nin bu eseri, o kadar önemsenmişti ki, ertesi yıl bütün Avrupa ülkelerinde lisansüstü eğitimde standart bir ders kitabı olarak okutulmaya başlanmıştı. Yeni maliye politikası anlayışında, maliye politikasında birinci öncelik kaynak tahsisinde etkinliğin sağlanmasına verilmiştir. Bunun nedeni, fonksiyonel maliye politikası anlayışına göre kaynak tahsisinde etkinlik sağlanmadan gelir dağılımını iyileştirme ve makroekonomik sorunları çözme olanağı bulunmadığı yönündeki inanıştı. Abba Lerner'in fonksiyonel maliye anlayışının en önemli özelliği, devletin çok sayıdaki ekonomik fonksiyonları arasında öncelikler silsilesini ortaya koymasıydı. Bu öncelikler silsilesinde devletin ekonomik fonksiyonları, "temel fonksiyonlar" ve "alt fonksiyonlar" olmak üzere iki ana başlık altında toplanmıştı. ${ }^{24}$

Önceliklerine göre devletin temel fonksiyonlar1;

- Kaynak dağılımında etkinliğin sağlanması,

- Gelir dağılımında adaletin sağlanması ve

- Ekonomik istikrarın sağlanmasıdır.

Devletin alt fonksiyonları ise,

- Fiyat istikrarının ve tam istihdamın sağlanması,

- Sürdürülebilir büyüme oranının yakalanması ve

- Ödemeler bilançosunda dengenin sağlanmasıdır.

Görüldüğü üzere, Abba Lerner'in fonksiyonel maliye yaklaşımı bir iktisat politikası olmaktan daha ziyade, ekonominin fiilen içinde bulunduğu koşullara göre

\footnotetext{
23 Söz konusu eserin orijinal ismi "The Theory of Public Finance: A Study in Public Economy" şeklindedir.

24 Bkz. Lerner (1941, 1943).
} 
şekillenen ve hangi durumda hangi politikanın [para politikasının mı? maliye politikasının mı? yoksa her ikisinin mi?] uygulanması gerektiğini ortaya koyan bir öneriler paketidir.

İkinci Dünya Savaşı'nın hemen sonrasında Keynes'in “Genel Teori” ile teorik çerçevesini çizdiği öneriler manzumesinin uygulamaya konulması konusunda hem politika yapıcıları, hem de akademisyenler arasında mutlak bir uzlaşı ortamı doğdu (Dullien, 2012). ${ }^{25}$ Duruma göre maliye politikas ${ }^{26}$ uygulamak iktisadi sorunların üstesinden gelmek için yeterliydi. Zaten, Bretton Woods sistemi altında para politikasının esnekliği azaldığından, makroekonomik yönetim için en iyi seçenek maliye politikasından başka bir şey değildi.

Rahatlıkla söyleyebiliriz ki, Keynes'in müdahaleci iktisat anlayışının temel uygulama aracı olan maliye politikası, özellikle 1945-1970 yılları arasında altın çağını yaşadı ve söz konusu dönemde yalnızca gelişmiş ülkelerde değil; gelişmekte olan ülkelerde de uygulanan makroekonomik politikaların omurgasını Keynesçi politikalar oluşturdu. Tabi söz konusu dönemde, maliye politikası pratik olarak uygulanmanın yanısıra, teorik olarak da özellikle batılı akademisyenlerin de etkisi ile büyük mesafe kat etti. $\mathrm{Bu}$ hususta ilk bakışta göze çarpanlar arasında Hollanda'dan Jan Tinbergen [1903-1994], Almanya'dan Richard A. Musgrave [1910-2007], ABD'den Paul Davidson [1930- ], ABD'den “Amerikall Keynes" lakaplı Alvin H. Hansen [1887-1975], Abba P. Lerner [1903-1982], Paul A. Samuelson [1915-2009], Robert M. Solow [1924- ] gibi dünya çapında ün yapmış ve bazıları da Nobel iktisat ödülü kazanmış akademisyenler yer almaktadır. ${ }^{27}$

1950-1960’lı yıllardaki ekonomi politikalarını, büyük ölçüde James Tobin ve Paul Samuelson'un öncülük ettiği Neo-klasik sentez şekillendirdi. Neo-klasik sentez, Neo klasik iktisat ile Keynesyen iktisadı uyumlaştırmaya çalışan ve orijini John R. Hicks'in [1904-1989] 1936'larda yaptığı çalışmalara dayanan bir yaklaşımdı. Kısa dönemde Keynes'in görüşlerinin, uzun dönemde ise klasiklerin görüşlerinin geçerli olduğu noktasından hareket eden bu yaklaşım, devletin ekonomiye müdahale etmesi gerektiğini ve

25 J. M. Keynes'in 1936 yllında yazmış olduğu Genel Teori'nin tanınmasında ve geniş toplum kesimleri tarafindan benimsenmesinde John Hicks' in önemli katklart olmuştur. Hicks 1937'de kaleme aldığ " Bay Keynes ve Klasikler" başlıkl makalesinde Keynes'in Genel Teori'de açıladığ görüşleri ile Klasik iktisadın temel ilkelerini bağdaştırmak suretiyle Keynesyen yaklaşım ile Klasik yaklaşımın bir sentezini oluşturmuştur. Söz konusu çalışmasinda Leon Walras' in genel denge modelinden faydalanan ve Keynes' in Genel Teorisi 'ni bu çerçevede değerlendiren Hicks'in görüşleri 1950'li ylllarda literatürde “Amerikalı Keynes" olarak bilinen Alvin Hansen tarafindan daha da gelişstirilmişstir.

26 Duruma göre maliye politikasından kastedilen, toplam talep yetersizliği halinde, genişletici [kamu harcamaların arttırıcı, vergileri kisıcı]; toplam talep fazlalığı halinde de daraltıcı maliye politikası [kamu harcamalarını kisıcl, vergileri arttıricı] uygulanmasidır.

27 Söz konusu akademisyenlerden Jan Timbergen, 1969 yllında; Paul Samuelson, 1970 yllinda; Robert Solow ise, 1987 yllında Nobel iktisat ödülüne laylk görülmüştür. 
ekonomi üzerinde hem maliye politikasının, hem de para politikasının etkin olduğunu savunuyordu. Nitekim bu dönemde maliye politikası ile para politikası birlikte uygulanmaya çalışılmış ancak Bretton Woods Sistemi'nin esnek bir para politikasına imkân vermemesi sebebiyle de maliye politikası ağırlıklı bir makroekonomik yönetim politikası izlenmiştir.

Kısmen 1967'de başlayan ve 1973'e değin süren Vietnam Savaşı ve 1973'de başlayan OPEC petrol şoklarının, kısmen de yanlış uygulanan maliye ve para politikalarının etkisiyle, başta $\mathrm{ABD}$ ve İngiltere olmak üzere birçok gelişmiş ülkede enflasyon tırmanışa geçti. Tabi ekonomideki kötü gidişat yalnızca enflasyonla sınırlı kalmadı, büyüme oranında gerileme, ciddi bir işsizlik sorunu, bütçe ve ödemeler bilançosu açıkları ortaya çıktı.

Özellikle enflasyon ve işsizlik gibi iki temel iktisadi sorunun eşanlı olarak yaşanması, genelde Keynesyen iktisada, özelde de maliye politikasına karşı şüpheleri topyekûn artırdı. Ortada daha önce eşine hiç rastlanmayan ve Keynes'in söylemleri ile tezatlık teşkil eden bir sorun vardı. O da, o zamana kadar Keynes'in makroekonomik dengeye ilişkin söylemlerinin adeta ampirik tasdiki olan Phillips eğrisinin ifade ettiği gibi, bir ekonomide enflasyon varsa, işsizliğin, işsizlik varsa da, enflasyonun olamayacağıydı. Sorunların gittikçe derinleşmesi, şaşkınlığı da beraberinde getirdi. Çünkü yüksek oranlı enflayonla işsizlik bir aradaydı ki bu adına daha sonra "stagflasyon"28 denilecek yeni bir iktisadi olguydu. Bu sorunun üstesinden standart Keynesyen politikalarla gelme olanağ mümkün değildi. Pek çok ekonomist Keynesyen politikaların bizzat kendisinin yeni istikrarsızlıkların ana kaynağı olduğunu iddia etmiş ve stagflasyonun ortaya çıkmasından ihtiyari-aktif maliye politikalarını sorumlu tutmuştur.

Uygulamada karşılaşılan bu açmazı, 1976-1979 yılları arasında İngiltere Başbakanı olan James Callaghan'ın Eylül 1976'da İşçi Partisi'nin Blackpool'da yaptığı bir konferanstaki konuşmasında geçen şu tarihi sözleri özetlemektedir:

"Biz durgunluktan çıkmak için sadece harcama yapıldı̆̆ını ve vergi indirimleri ile harcama artışlarının istihdamı arttırmak için yapıldığını düşünürdük. Bütün samimiyetimle söylüyorum, artık böyle bir seçenek yok! ve hiçbir zaman da şimdiye

28 Stagflasyon enflasyon içinde durgunluk demektir. Ingilizce "stagnation" ile "flation" kavramlarının birleștirmesi suretiyle elde edilmiş olan stagflasyon kavramı, 1970'lerin başlarında Neo-Avusturya İktisat Okulu'ndan Friederic August von Hayek [1899-1992] ve Ludwig von Mises [1881-1973] tarafindan iktisat literatürüne kazandırllmış bir kavramdır. Yüksek bir enflasyon oranının, kullanılmayan üretim kapasitelerinin, işsizliğin ve yetersiz bir büyüme hızının birlikte yaşandiğı bir ekonomik olay ifade etmek için kullanılan stagflasyon, Keynesyen iktisat açısından ciddi paradoksal bir olguya işaret etmektedir. Stagflasyonun yaşandiğ bir ekonomide işsizlik artarken fiyatlar genel düzeyi de artmaktadır. O nedenle Keynesyen kuram çerçevesinde stagflasyonu açıklama olanağ yoktur. 
kadar olduğu gibi olmayacak. Bu mekanizma, ekonomiye yüksek dozda enflasyon enjekte ederek ve bunu yüksek işsizliğin takibi ile çalışmıştır. Bu durum son 20 yllın tarihi olayldır!" (Aktaran; Issing, 2010).

Uygulamada bu sorunlar yaşanırken, akademik camiada Keynesyen iktisada ve onun maliye politikasına yönelik eleştiriler çoktan başlamış ve tam gaz devam ediyordu. Öncelikle Milton Friedman'ın başını çektiği monetarist akım olmak üzere, James Buchanan ile Gordon Tullock'un öncülüğünde geliştirilen kamu tercihi teorisi, Arthur Laffer ve Jude Wanniski'nin öncülüğünü yaptığı arz yönlü iktisat, Robert Lucas'ın öncülüğ̈n̈̈̈ yaptığı yeni klasik iktisat, Friedrich August von Hayek'in kurucusu olduğu Neo-Avusturya iktisat ekolü gibi klasik iktisadın yeni versiyonunu temsil eden ne kadar görüş varsa hepsi genelde Keynesyen iktisadı, özelde de maliye politikasını adeta günah keçisi ilan etmişti bile!

Özellikle Milton Friedman'ın teorik ve ampirik çalışmaları, Keynesyen iktisat üzerindeki şüphelerin artmasında ciddi bir rol oynadı. Keynesyen politikaların etkinliğini sorgulayan Friedman, özellikle crowding-out ${ }^{29}$, Keynesyen çarpan mekanizması ve uzun dönem Phillips eğrisi üzerinden Keynesyen iktisadı adeta eleştiri bombardımanına tuttu. Friedman'ın eleştirilerini, arz yönlü iktisatçıların; Keynes'in, ekonominin talep cephesine odaklandığı, ekonominin arz cephesini ihmal ettiği, oysaki büyüme ve istihdam açılarından ekonominin arz cephesinin talep cephesinden daha önemli olduğu yönündeki argümanları izledi.

Keynesyen iktisadı eleştirmekte Virginia İktisat Okulu'ndan Buchanan ve Tullock'un öncülüğünü yaptığı kamu tercihi ve anayasal iktisat yaklaşımı da, diğerlerinden aşağ 1 durmadı. Devleti ve devletin büyüklüğünü o denli abarttılar ki; tartışmayı, "kendi büyüklüğ̈̈ altında ezilen deniz canavarı" anlamına gelen ve Thomas Hobbes tarafından 1600 ’lü yıllarda kullanılan "Leviathan"a kadar götürdüler ve Keynesyen iktisada dayalı uygulamaların politik analizini yaparak, "devletin başarısızliğl" argümanını geliştirdiler. $\mathrm{Bu}$ argümana dayalı olarak da devletin mutlaka küçültülmesi gerektiğini, denk bütçeden asla taviz verilmemesini, devlet müdahalesinin minimize edilmesini ve hatta devletin vergi toplama, harcama yapma, borçlanmasına üst sınırlama getirilmesini ve bunun için de mali anayasa yapılması önerisini ortaya attılar.

Crowding out; Türkçe literatürde dişlama etkisi, kovma etkisi, engelleme etkisi, kalabalıklaşma etkisi, ayağını kaydırma etkisi, iteleme etkisi, özel kesimin ötelenmesi, özel kesimin piyasa dışına itilmesi olgusu gibi oldukça farklı kavramlarla ifade edilmekte ve bütçe açıklarının iç borçlanmayla finansmanı sonucu ödünç verilebilir fonlar piyasasında faizlerin yükselmesi, yükselen faizlerin de faize duyarl özel sektör yatırım ve harcamalarının olumsuz yönde etkilemesi sonucu çıktı düzeyinin olması gerekenden düşük sevide gerçekleşmesidir. Detaylı bilgi için bkz. Şen, Sağbaş \& Keskin (2007), Şen \& Kaya (2014). 
Gerek akademik alandaki tartı̧̧malar, gerekse uygulamada yaşanan sorunlar, 1945 sonrası dönemde maliye politikasının adeta alternatifi olmayan ve terkedilemez bir politika aracı olduğu yönündeki mutlak inancı yıktı. Dahası, 1970'lerin sonları ile 1980'lerin başlarında Keynesyen iktisat, hemen hemen modası geçmişle aynı şeyi çağrıştıran aşağılayıcı bir terim oldu (Blinder, 1988).

Keynesyen iktisat ve maliye politikasına bakıştaki bu tersine dönüşte, maliye politikasının yapısından kaynaklanan sorunlar da [popülizme açık olması, gecikmeler sorunu yaşaması, rasyonel beklentileri dikkate almaması, maliye politikası çarpanının değerinin aşırı küçük olması ve dolayısıyla reel çıktı düzeyi ve istihdam üzerinde pek fazla bir etkisinin olmaması, değiştirilemez ve katı olması, esnekliğe yer bırakmaması, vergi sisteminde yer alan artan oranlı vergilerin mali sürüklenme olgusunu ortaya çıkarması ve bunun da resesyondan/durgunluktan çıkışı engellemesi, vb. $]^{30}$ etkili oldu. Maliye politikasına yönelik söz konusu negatif bakış, 1970'li yıllarla sınırlı kalmamış; 1980'li, 1990 'lı ve hatta bir ölçüde de 2000'li yılların ilk yarısına kadar sürmüştür. ${ }^{31}$

Özellikle 1980 ve 1990'lı yıllarda maliye politikası pek önemsenmeyen bir politika halini aldı ki, bu dönemde sadece maliye politikasının etkinsizliği değil, aynı zamanda bazı iktisatçılar tarafından bütçe açıklarının etkin bir biçimde kısılmasının ekonomik büyümede artışa neden olup olmayacağı bile sorgulanmaya başlandı (Dullien, 2012). Literatüre "maliye politikasının Keynesyen olmayan etkileri" 32 başlığ ile giren bu minvaldeki tartışmalar, Giavazzi \& Pagano'nun (1990) çalışması ile başladı. Bu çalışmayı Giavazzi \& Pagano (1996), Giavazzi, Jappelli \& Pagano (2000), Afonso (2001) gibi maliye alanında uluslararası arenada tanınan akademisyenlerin çalışmaları izledi. Bunların tam aksine, maliye politikasının etkinliği konusunda diğer bazı ampirik bulgular farklı şeyler söylese de (Arestis, 2011), maliye politikası ikinci plana atılmaktan kendini kurtaramadi.

IMF, Dünya Bankası gibi kuruluşların da etkisi ve yönlendirmeleriyle, Keynes'in talep yönlü politikaları yerini Neo-liberal akımın argümanlarına dayanan politikalara bıraktı. "Ekonomideki sorunların temel kaynağının bizatihi devletin ekonomiye

30 Bu minvaldeki tartışmaların detayları için bkz. Blanchard, Giovanni \& Paolo (2010), Tokucu \& Sarıdoğan (2010).

31 Belirttiğimiz dönemde maliye politikasına bakıştaki mesafeli ve karşı duruş o denli fazlaydı ki, dünyanın önde gelen bazı akademisyenleri maliye politikasını akademik çalışmalarında bir iktisat politikası aracı olarak dikkate almaya bile gerek görmediler. Profesör Sebastian Dullien 'in aktardığına göre, örneğin, David Romer'in çok bilinen ve hatta lisansüstü düzeyinde okutulan "Advanced Macroeconomics-İleri Düzey Makroekonomi" başlıklı ders kitabının 1996 tarihli ilk baskısında maliye politikası kavramına bir kez dahi yer verilmez iken, para politikası kavramina tam tamina 36 kez yer verilmiştir (Dullien, 2012: 6-7).

32 Orijinal ismi "Non-Keynesian effects of fiscal policy" şeklindedir. 
müdahalesi olduğu" tezinden hareket eden bu akımlar ${ }^{33}$, Klasiklerin söylemlerine geri dönülmesi gerektiğini savunarak, varsa yoksa devletin küçültülmesi üzerine odaklanmışlardı. 1980'ler boyunca Neo-liberal akımın temel ilgi odağı deregülasyon; özellikle de finansal piyasaların deregülasyonu oldu, ekonominin hemen her sahasında devletin rolünü azaltmaya ve alanını daraltmaya yönelik politikalar ön plana çıktı.

Bunun yanında özelleştirme, denk bütçe, mali sürdürülebilirlik, faiz dışı fazla, yapısal uyum politikaları, Washington uzlaşısı ${ }^{34}$, merkez bankalarının bağımsızlığ1, enflasyon hedeflemesi gibi konular 1980 ve sonrasının hâkim makroekonomik politika öncelikleri arasına girdi. Söz konusu süreçte Keynesyen iktisat ve onun temel uygulama aracı olan maliye politikası "out", devletin küçültülmesi ve bu bağlamda özelleştirme, denk bütçe ve para politikası "in” oldu. Bu eğilim büyük ölçüde ta ki yeni bir kriz çıkana kadar devam etti. Maliye politikasına biçilen misyon ise sadece denk bütçenin sağlanması ve borçların sürdürülebilirliğinin temini idi.

Genel olarak ifade edebiliriz ki, gerek 1980'li yıllar, gerekse 1990'lı yıllar maliye politikası açısından pek iç açıcı yıllar değildi. Söz konusu dönemde maliye politikası, hep aktif bir iktisat politikası olmaktan uzak kaldı. Maliye politikasına ilişkin tartışmalar, enflasyon ve ödemeler bilançosu sorunlarının kaynağı olarak görülen yüksek bütçe açıkları ve kamu borçları ile uzun dönemli sürdürülebilir büyümenin sağlanmasına yönelik vergi sistemleri ve harcama programlarına doğru kaydı (Hemming, Kell \& Mahfouz, 2002). Bunda özellikle 1990'lı yıllarda iktisat politikalarının dizaynında iktisadi hâkim görüşün Yeni Keynesyen İktisat ${ }^{35}$ olması (Tokucu \& Sarıdoğan, 2010) ve bu görüşü

33 Monetarizm, arz yönlü iktisat, kamu tercihi teorisi ve yeni klasik makro iktisat gibi akımlarl ihtiva eder. Bu akımların ortak özelliği, Keynesyen politikalara topyekün muhalif olmalarl, devletin küçültülmesini savunmaları, devlet müdahalesini reddetmeleri ve piyasa ekonomisinin kendi haline bırakılmasi gerektiğini savunmalarıdır.

341989 yllında Uluslararasi Ekonomi Enstitüsünün [The Institute for International Economics] kidemli uzmanlarından John Williamson tarafindan söz konusu enstitünün yaptı̆̆ bir toplantı için hazırladiğl ve 1950 'lerden beri izledikleri eski kalkınma politikalar yerine Latin Amerika ülkelerinin izlemesi istenilen 10 maddelik Neo-liberal öneriler paketidir. Öneri paketi sırasıyla şunları içeriyordu: i) Mali disiplinin sağlanması, ii) Kamu harcama önceliklerinin yeniden sıralanması, iii) Dış ticaretin liberalizasyonu, iv) Rekabetçi bir döviz kurunun benimsenmesi, v) Faiz oranlarının serbest bıraklması, vi) Özelleştirme, vii) Yabancı sermaye girişleri üzerindeki kısıtlamaların kaldırılması, viii) Deregülasyon, ix) Kayıtdışı sektöre mülkiyet haklarını elde etme olană̆ının tanınması, x) Vergi tabanını genişletecek buna karşın marjinal vergi oranlarını düşürecek bir vergi reformunun hayata geçirilmesi. Tüm bu önerilerin Washington'un da benimseyeceği öneriler olduğu noktasından hareketle, "Washington Uzlaşısı-Washington Consensus" olarak isimlendirilmiştir.

35 Öncülügünü Arthur Okun, Stanley Fischer, Ben Bernanke, John Taylor, Oliver Blanchard, Gregory Mankiw, Janet L. Yellen gibi dünyanın önde gelen ve en çok tanınan, en çok itibar edilen makro iktisatçılarının öncülük ettiği bu iktisat ekolü, literatürde "Yeni Keynesyen Yaklaşım” veya "Yeni Keynesyen Teori”" gibi kavramlarla da ifade edilmektedir. Bu ekolün temel odaklanma alanı, makroekonomik sorunlarin mikro temelleri ve rasyonel beklentiler üzerinedir. Fiyat ve ücret yapışkanlıklarl, eksik rekabet ve piyasa başarısızlıkları, eşgüdüm sorunu gibi temel konulara odaklanan Yeni Keynesyen iktisat, bu konular yanında ters seçim, ahlaki riziko, enformasyon, dışsallıklar gibi kamu ekonomisi alanına giren konulara temas etmiştir. Yeni Keynesyen iktisat, 
savunan akademisyenlerin dünya ekonomisine yön veren kurumların kilit noktalarında görev yapmaları da bir ölçüde etkili oldu. ${ }^{36}$

Ancak Japonya'nın 1990'ların başlarında durgunluğa girmesi, maliye politikası üzerindeki tartışmaları tekrar alevlendirdi. Japonya'nın yanında 1997 Asya Krizi ile Kore, Endonezya ve Tayland'ın şiddetli bir resesyona girmesi ve 2000'lerin başlarında da Avrupa ve ABD'de görülen resesyon belirtileri genişletici maliye politikasının ekonomik faaliyetleri teşvik etmedeki rolünü tekrar gündeme getirdi [(Hemming, Kell \& Mahfouz, 2002), (Kopcke, Tootell \& Triest, 2006)].

Maliye politikası, 2000'li yılların başından itibaren yavaş yavaş makroekonomik politika dizaynında yer almaya başladı. 2001 yılında ABD'de ortaya çıkan resesyon ve Başkan George W. Bush'un resesyonla mücadelede vergi indirimlerini devreye sokması ve bunun en liberal kesimler tarafından bile desteklenmesi maliye politikasının dönüşünün ilk işaretleri oldu. Ancak Avrupa'da maliye politikasının konjonktürel dalgalanmaları minimize etmedeki rolüne ilişkin mesafeli bakış büyük ölçüde 2000'li yıllar boyunca da devam etti (Dullien, 2012). ABD'de baş gösteren ve hızla diğer ülkelere yayılan son kriz ise bu mesafeli bakışı tersine çevirmeye yetti. Krizinin üstesinden gelmede birçok ülkenin peş peşe mali paketleri devreye sokması maliye politikasının muhteşem dönüşü olarak lanse edildi ve hatta o kadar ki bazı kesimler bunu "Keynesyen rönesans" olarak adlandırmaktan bile geri durmadilar. ${ }^{37}$

\section{Son Krizle Birlikte Maliye Politikasına Bakışta Ne Değişti?}

Globalleşme ile ekonomik krizler de evrim geçirdi. Sirayet etkisi ile artık bir ülkedeki kriz, hızla diğer ülkeleri de etkisi altına alabilmektedir. Bu bağlamda, son 20-30 yılda hem krizlerin sıklığı, hem de şiddeti arttı. Bunda iletişim ve teknolojik alandaki gelişmeler ile uluslararası piyasaların birbirine eklemlenmiş olmasının çok büyük payı olduğu söylenebilir. Tüm bu unsurların da etkisi ile krizler çıktığı ülke ile sınırlı kalmamakta; sirayet etkisi ile hızla küresel bir kriz haline dönüşebilmektedir.

İstisnasız hemen her kriz döneminde maliye politikası hatırlanır oldu. Son yaşanan kriz de bundan farksızdır. Daha önce de değindiğimiz gibi, ABD kaynaklı finansal

ekonomide istikrar politikası aracı olarak para politikasının; buna karşın, maliye politikasının ise denk bütçe anlayışıın riayet edilerek yürütülmesi gerektiğini savunmaktadırlar.

36 Bir önceki FED Başkanı Prof. Ben Bernanke ile şu an bu görevi ifa eden Prof. Janet Yellen, önce IMF Birinci Başkan Yardımcllğ̆l, daha sonra İsrail Merkez Bankası Başkanlığı ve şimdi de FED Başkan Yardımcılı̆̆ görevini ifa eden Prof. Stanley Fischer, halen IMF Başekonomistliği görevini yürüten Prof. Oliver Blanchard bunun tipik örnekleridir.

${ }^{37}$ Bkz. örneğin; Issing (2010), Arestis (2012b). 
kriz Ağustos 2007'de ABD'de emlak piyasalarında yaşanan sorunlar nedeniyle başladı. Ancak burada önemle belirtelim ki, birazdan aşağıda da değineceğimiz gibi, kriz, emlak piyasasında yaşanan sorunlar nedeniyle başlasa da, sorunun asıl kaynağı ABD ekonomisindeki likidite bolluğunun varlık değerlerini yapay bir biçimde arttırmasıydı (Şen \& Çalışkan, 2009). Lehman Brothers'ın iflas etmesi, maliye politikası açısından adeta bir dönüm noktası oldu. FED, krizi gevşek para politikası ile aşmayı denedi ve gevşek para politikasına ait elinde ne kadar enstrüman varsa hepsini devreye soktu. Ancak para politikası kriz üzerinde olumlu bir etkide bulunmadı. Gözden kaçırılan husus, 2007'de başlayan krizin kendine münhasır özellikleri bulunması ve daha öncekilerden farklı olmasıydı. Krizin asıl nedeni, düşük risk fiyatlaması sonucu ortaya çıkan kaldıraç etkisiydi (Feldstein, 2009). ABD’nin dış açıklarını finanse etmek için gevşek para politikası uygulaması, Çin'in sahip olduğu muazzam döviz rezervlerinin önemli bir kısmını bu ülke tahvillerine plase etmesi gibi nedenlerle ABD ekonomisinde likidite bolluğu ortaya çıktı. Ortaya çıkan likidite bolluğu faizleri düşürdü ve kredi verilebilir fonların aşırı ölçüde artmasına neden oldu. Tüm bu gelişmeler de, varlık değerlerinin balonlaşmasını ve "köpük ekonomisi" sorununu ortaya çıkardı ve sonuçta da konut fiyatları yükseldi (Şen \& Çalışkan, 2009). Bu olumsuzluklara karşın, bankalar düşük faizli kredi verme politikalarını aldırmaksızın sürdürdüler. Öyle ki, daha önceleri kredi verilmesi sakıncalı bulunan kesimler dahi fonlanmaya başlandı (Gorton, 2008). ${ }^{38}$

Riskli konut kredilerinin faiz oranlarının yükselmesi, bir anda bu sektörde risk fiyatlamalarının doğru yapılmadığı intibaını uyandırdı. $\mathrm{Bu}$ da, risklerin yeniden fiyatlanmasına; riskleri yeniden fiyatlanan konutların fiyatlarında düşüşe ve bununla bağlantılı olarak da konut sektörüne ait menkul kıymetlerin fiyatlarında düşüşe neden oldu. Tüm bu gelişmeler de, tüketim harcamalarının azalması ve konut sahiplerinin servetlerinin erimesi ile sonuçlandı (Feldstein, 2009).

Daha önceki benzer ekonomik sorunlar FED'in sert faiz artırımına gitmesinden kaynaklandığı için sorunun üstesinden gelmek amacıyla faiz oranlarında indirime gitmek yeterli oluyordu. Oysaki son krizde durum bundan çok farklıydı ve sorunun kaynağ yüksek faiz oranları değildi. O nedenle de faiz indirimleri yoluyla ekonomide canlanmayı sağlamak mümkün olmadı. Nominal faiz oranlarının sıfıra dayandığı bir durumda, artık para politikasının iktisadi faaliyetleri canlandırmada bir araç olarak kullanılabilme olanağı yoktu. Bir bakıma para politikası doğal sınırlarına ulaşmış ve bir nevi “Keynes'in likidite tuzağı" durumu ortaya çıkmıştı. Yani, para politikası bir iktisat politikası seçeneği olmaktan çıkmış görünüyordu. Böyle bir durumda elde tek seçenek kalıyordu; o da, uzun yıllardır ihmal edilen, mesafeli durulan diğer bir iktisat politikası aracı olan maliye politikasından başka bir şey değildi.

38 Burada önemle vurgulayalım ki, krizin nedenlerini tartışmak, bu çalışmanın amacı ve kapsamı dışındadır. Burada bizi ilgilendiren temel konu neden para politikasının krizle mücadelede işlevsiz kaldiğıdır. 
Son yaşanan kriz öncesinde, kısa dönemli ve geçici şokların para politikası ile etkin bir biçimde bertaraf edilebileceği ağırlıklı olarak Neo-liberal akım tarafından adeta aksiyom olarak kabul görüyordu (Ferreiro, Gomez \& Serrano, 2013). Krizin ortaya çıkması ile birlikte söz konusu aksiyom yerini, maliye politikasına yönelişe bıraktı. Uygun ortam, uygun zaman ve uygun koşullar oluşturulduğu takdirde maliye politikasının iktisadi faaliyetleri etkilemede ve şokların olumsuz etkilerinin üstesinden gelmede etkin bir rol oynayabileceği görüşü geniş bir yelpazedeki kesim tarafından benimsenmeye başlandı.

Tartışmalar politika yapıcılar ve gazeteciler yanında akademik camiada da geniş yankı uyandırdı. Yale Üniversitesi'nden 2013 yılı Nobel iktisat ödülü sahibi Robert J. Shiller'den, Prinston Üniversitesi'nde 2008 yılı Nobel iktisat ödülü sahibi Paul Krugman'dan, Columbia Üniversitesi'nden 2001 yılı Nobel iktisat ödülü sahibi Joseph Stiglitz'den, yine Berkeley Kaliforniya Üniversitesi'nden 2001 Nobel iktisat ödülü sahibi George Akerlof'a, J. Bradford DeLong'a, James K. Galbraith'a kadar dünyanın en tanınmış ve en itibarlı akademisyenleri, krizden ve akabinde ortaya çıkan global resesyondan çıkış için maliye politikasının devreye sokulması noktasında birleştiler. Maliye politikasının makroekonomik politika arenasına dönüşü, böyle bir uzlaşı ortamında gerçekleşti. Aslında bu uzlaşı ortamı bir bakıma hem resesyonun şiddetini, hem de maliye politikasının resesyonla mücadeledeki potansiyel etkinliği konusundaki geçici iyimserliği yansitmaktaydi (Auerbach, 2012).

\section{Maliye Politikasına Bakışta Gelinen Nokta}

Son krizle birlikte, sadece otomatik stabilizatörlerce ${ }^{39}$ desteklenen bir para politikasının kriz dönemlerinde ekonomide istikrarı sağlamada yetersiz ve etkisiz kaldığı, o nedenle de ihtiyari-aktif maliye politikalarının da devreye sokulması gerektiği iyiden iyiye geniş bir yelpazede dillendirilmeye başlandı. Aslında bu durum, maliye politikasına bakıştaki ciddi bir dönüşümün işaretiydi. Oysa ki 1980'lerden 2000'lerin başlarına kadar geçen yirmi yıldan daha uzun süre boyunca, aktif maliye politikasına bakıştaki politik ön yargılar ve kaygılar yanında özellikle şu iki argüman maliye politikasının pasifize edilmesinde etkili oldu: ${ }^{40}$

- Konjonktürel dalgalanmaların üstesinden gelinmesinde otomatik stabilizatörler fazlasıyla yeterlidir. İlaveten bir de aktif maliye politikasına ihtiyaç yoktur.

39 Ekonomik dengenin sağlanması ve sürdürülmesinde kendiliğinden işlevleri olan, sistemin içinde var olan, denge să̆layıcı etkiler yaratan kurumlardır. Örneğin; artan oranlı vergiler, işsizlik sigortası ödemeleri, bütçe açı ve fazlaları, birey-aile ve kurum tasarruflarl ile toprak mahsullerine ödenen mali yardımlar otomatik stabilizatörlere örnektir. Bu konu ile ilgili detaylı bilgi için bkz. Şen \& Kaya (2013).

Bu tartışmaların detayları için bkz. Auerbach, Gale \& Harris (2010), Auerbach (2012). 
- Günümüzde hem merkez bankalarının bağımsızlık dereceleri artmış, hem de para teorisi ve politikasında ciddi gelişmeler olmuştur. Bir para politikası aracı olarak faiz oranları, hem enflasyonun kontrol edilmesinde, hem de konjonktürel dalgalanmaların üstesinden gelmede gereğini fazlasıyla yapabilecek durumdadır. O nedenle başka bir politikaya ihtiyaç yoktur.

Ancak maliye politikasının aktif olarak kullanımına karşı ileri sürülen söz konusu argümanlar, 1929 Buhranı ile karşıllaştırılabilecek kadar şiddetli bir küresel kriz karşısında hem yetersiz, hem de etkisiz kalmıştı. Bunun üzerine tartışmaların odağı iradiaktif maliye politikasına kaymış; uygun zamanda, uygun dozda, uygun koşullarda ve uygun araçlarla uygulanacak bir maliye politikasının ekonomik faaliyetleri etkilemek suretiyle krizden çıkışta etkili olabileceği akademik, bürokratik ve siyasi çevrelerde tartışılmaya başlanmıştır.

Nitekim maliye politikasına bakıştaki bu değişimin dönüm noktasını, Eylül 2008'de Lehman Brothers'in çökmesi oluşturdu (Arestis \& Sawyer, 2010). "Klsa dönemli ve geçici şokların üstesinden yalnızca para politikası gelebilir." şeklinde adeta aksiyom haline gelen ve para politikası gibi bir iktisat politikası olan maliye politikasına bakıştaki mesafeli duruş krizle birlikte büyük ölçüde azaldı. Geçmiş yıllarda, maliye politikasına karşı hep ihtiyatlı bir duruş sergileyen IMF'nin bile bakışı son krizle birlikte değişti. IMF'nin maliye politikasına bakışındaki bu değişikliği, kurumun en tepe noktasında görev yapmış bir isim, eski başkan Dominique Strauss-Kahn'ın itiraf niteliğindeki şu sözleri bütün çıplaklığı ile ortaya koymaktadır:

"Kriz öncesinde ekonomileri oldukça iyi yönettiğimizi düşünürdük. Bu düşüncemizin dayanağı olan Washington Uzlaşısı çok sayıda meziyete sahipti. Basit para ve maliye politikası kuralları ekonomik istikrarı garanti edecekti. Deregülasyon ve özelleştirme, büyüme ve refahı sağlayacaktı. Finansal piyasalar kaynakları en verimli olduklarl alanlara kanalize edecek ve etkin bir biçimde kendi kendilerini denetleyeceklerdi. Ayrica artan küreselleşme de bütün yükü çekecekti.

Krizle birlikte bütün bunlar çöktü. [Şimdi] Washington Uzlaşısı gerimizde kaldı. Bize düssen görev istikrarın temellerini yeniden tesis etmek, bunlarl zaman testine tabi tutmak ve küreselleşmenin bir sonraki aşamasını herkes için avantajlı hale getirmektir. Söz konusu yeniden inşa için şu üç temel yaklaşıma ihtiyaç vardır: Ekonomik politikalara yeni bir yaklaşım, sosyal uyuma yeni bir yaklaşım ve işbirliği ve çok taraflılı̆̆a yeni bir yaklaşım.

[Peki ya] maliye politikasına ne demeli? Eski paradigmaya göre, maliye politikası kesinlikle makroekonomik politikanın "ihmal edilen çocuğu” idi. Rolü konjonktürel dalgalanmalara göre artan ve azalan bütçe açıklarına izin veren otomatik stabilizatörler ile sinırl idi. Ihtiyari-aktif maliye politikasına derin şüpheyle bakılıyordu. Ancak enerjisi tükenen para politikası ve dizleri üzerine çöken bir 
finansal sistem varken maliye politikası kriz dönemlerinin uyuyan güzeliydi. İktisat politikasinın bu unutulan enstrümanı azalan toplam talebin imdadina yetişti ve dünyayı bir ekonomik felaketten korudu. Maliye politikasını yeniden düşünmek durumundayı." (Strauss-Khan, 2011).

Öte yandan, Avrupa Merkez Bankası eski yönetim kurulu üyesi Otmar Issing’in ifadesi de Dominique Strauss-Kahn'ın sözleri kadar dikkat çekicidir: “Keynesyen rönesans sürpriz olarak görülmemeli. [Çünkü] Küresel ekonomi 2007'de yalnızca 1929 Büyük Buhranı ile karşılaştırılabilecek derecede şiddetli bir krizin içine düştü.” (Issing, 2010).

Akademik camiada da maliye politikasına bakışta ciddi bir değişim ortaya çıktı. Krizle beraber maliye politikasına bakışta gelinen noktayı Neo-klasik iktisat geleneğinden gelen Martin Feldstein'in şu ifadeleri özetliyor:

"Daha iki yıl öncesine kadar [2007], maliye politikasinın konjonktürel dalgalanmaları azaltmada etkin bir politika aracı olmadı̆̆ yönünde yaygın bir uzlaşı vardl. Şimdi ise Washington'daki ve dünyanın dört bir yanındaki hükümetler, üniversiteler ile iş âlemi dâhil geniş bir yelpazedeki iktisatçılar tarafindan desteklenen büyümeyi teşvik edici oldukça geniş kapsamlı mali paketler uygulamaya konuluyor." (Feldstein, 2009).

Yukarıdaki açıklamalardan bizim çıkarımımız, maliye politikasına biçilen rolün hala sınırlı düzeyde olduğu ve yalnızca kriz dönemleri ile özdeşleştirildiği yönündedir. Gelinen noktada, makroekonomik istikrarın sağlanmasında para politikasının hala geniş kesimler tarafından önemsendiğini, ona karşı bir umudun beslendiğini, dominant iktisat politikası aracı olma işlevini ve rolünü sürdürdüğünü; maliye politikasının ise sadece para politikasının işlevselliğini yitirdiği şiddetli resesyon ve durgunluk dönemlerinde devreye giren olağan dışı bir iktisat politikası enstrümanı gibi muamele ile karşı karşıya olduğunu görmekteyiz. Tabi bunda birazdan da değineceğimiz gibi maliye politikasının etkinliğine ilişkin teorik ve ampirik çalışmaların ve bu çalışmaların bulgularının ciddi bir payı olduğunu da göz ardı etmemek gerekir. Ancak hal böyle olsa da, dün olduğu gibi bugün de maliye politikasının ekonomik krizlerin imdatçısı olarak dikkatleri üzerine topladığından ve ciddi bir tartışmanın merkezinde olduğundan da şüphe yoktur.

Krizle mücadele için birçok ülkenin peş peşe mali paketleri devreye sokması sonrasında genelde ihtiyari-aktif maliye politikası, özelde de bu paketlerin etkinliği sorgulanmaya başlandı. Alevlenen maliye politikası eksenli tartışmalarda şu sorular ön plana çıktı: Acaba maliye politikası toplam talep düzeyini ve dolayısıyla ekonomik büyümeyi ne yönde ve ne miktarda etkiler? Eğer bir etkide bulunuyor ise bu etki konjonktürel dalgalanmaları azaltıcı [countercyclical] yönde midir? yoksa arttırıcı [procyclical] yönde midir? Açıktır ki, bu soruların cevabı da maliye politikası çarpanının işareti ve büyüklüğünde saklıdır. Maliye politikası çarpanı, diğer değişkenler sabitken 
kamu harcamalarındaki 1 TL'lik artışın veya vergilerdeki 1 TL'lik indirimin veya kümülatif olarak her ikisindeki eşanlı bir değişmenin yani mali etki paketinin GSYİH üzerinde ne miktarda bir değişme meydana getirdiğini gösteren bir katsayıdır. Çarpanın "1" değeri alması, GSYİH'nin yapılan kamu harcaması veya vergi indirimi veyahut da her ikisinin kümülatifi kadar arttığını; " 0 " ile " $l$ " arasında bir değer alması, ekonominin büyüdüğünü ancak bu büyümenin devreye sokulan mali paketten daha düşük olduğunu gösterir. Çarpanın değerinin 1'den büyük olması ise -ki bu arzulanan bir durumdur.uygulanan maliye politikasının hedefine ulaştığını, devreye sokulan mali etki paketinin toplam talep ve dolayısıyla GSYİH üzerinde kendisinden daha büyük bir etkide bulunduğunu ifade eder. Maliye politikası çarpanının sıfır değeri alması ise hiç de arzulanmayan bir durum olup; mali etki paketinin ekonomi üzerinde ters [negatif] etkide bulunduğunu göstermektedir ki bu hiçbir biçimde istenmeyen bir gelişme olup; crowdingout'a işaret eder. Böyle bir durumda ise tersine etki yapacak bir mali etki paketini yani daraltıcı maliye politikasını devreye sokmak gerekir. Görüldüğü üzere, maliye politikası çarpanının değeri ve işareti, devreye sokulan maliye politikasının etkinliği konusunda politika yapımcılarına fikir ve yön vermesi bakımından hayati önem taşımaktadır.

Çarpan konusu, maliye politikasının en tartışmalı alanlarından biridir. Resesyon, durgunluk gibi konjonktürün daraldığı ve dip yaptığı dönemlerde uygulanacak genişletici bir maliye politikasının toplam talep ve dolayısıyla ekonominin reel büyüme düzeyi üzerinde ne kadarlık ve ne yönde bir etkide bulunacağı maliye politikası çarpanının büyüklüğüne ve işaretine bağlıdır.

Ampirik çalışmalar ${ }^{41}$ farklı sonuçlar ortaya koymakla birlikte, söz konusu çalışmaları baz alarak maliye politikası çarpanına ilişkin şu çıkarımları yapabiliriz: Maliye politikası ülkelerin özelliklerine bağlı olarak değişmektedir. Para, maliye ve yapısal politikalar arasındaki koordinasyon, döviz kuru rejimi, kamu kesiminin borç düzeyi, uygulanan para politikası [gevşek mi? sıkı mı?], seçilen maliye politikası enstrümanı [vergi, harcama veya her ikisi], cari işlemler dengesi, ekonominin dışa açıklık derecesi, ekonominin finansal gelişmişlik düzeyi, beklentiler gibi ülkeye özgü faktörler de maliye politikası çarpanı üzerinde etkili olmaktadır.

Tüm bunları da dikkate alarak maliye politikasının etkinliğini ölçmede bir araç olan maliye politikası çarpanını ele alan ampirik çalışmalardan faydalanarak şu çıkarımları yapabiliriz:

41 Bu konunun detaylarl için bkz. Briotti (2005), IMF (2008), Alesina \& Ardagna (2010), Romer \& Romer (2010), Auerbach, Gali \& Harris (2010), Barro \& Redlick (2011), Delong \& Summers (2012), Auerbach (2012), Auerbach \& Gorodnichenko (2012), De Mello (2013), Ferreiro, Gomez \& Serrano (2013), Ilzetzki, Mendoza \& Vegh (2013), Jha, Mallick, Park \& Quising (2014). 
- Maliye politikası çarpanının hesaplanmasında kullanılan ekonometrik yöntem, çarpanın değerini etkiler. Yani, maliye politikası çarpanı tercih edilen ekonometrik yönteme bağlı olarak değişmektedir.

- Çarpanın değeri birçok faktöre bağlıdır. Genel olarak gelişmekte olan ülkelerde çarpanın değeri gelişmiş ülkelere nazaran daha küçüktür. Dahası, gelişmiş ülkelerin aksine verilerin yetersiz olması ve güvenilir olmaması, kurumsal zayıflıklar gibi nedenlerle gelişmekte olan ülkelerde maliye politikasının büyüklüğü ve işaretine ilişkin net bir sonuca ulaşma olanağı da yoktur.

- Kamu harcamaları çarpanı ile vergi çarpanının değeri birbirinden farklıdır. Özellikle maliye politikasına gevşek para politikasının eşlik etmesi durumunda kamu harcamaları çarpanının değeri birden çok daha büyük olmaktadır.

- Özellikle kısa dönemde kamu harcamaları çarpanının değeri, vergi çarpanından daha büyüktür.

- Maliye politikası çarpanının değeri ve büyüklüğü konjonktürün evrelerine bağlı olarak farklılık göstermektedir. Konjontürün daralma ve dip evrelerinde maliye politikası çarpanının değeri daha yüksek olmaktadır.

- Maliye politikası ile para politikası ve hatta finansal politikalar arasındaki koordinasyon maliye politikası çarpanının değerini etkilemektedir. Genel olarak genişletici maliye politikasının gevşek bir para politikası ile birlikte uygulanması, çarpanın değerini 1'in üzerine çıkaracaktır.

- Para ve maliye politikaları arasında koordinasyon mevcut iken, nominal faiz oranının sıfıra yaklaşması durumunda kamu harcamaları çarpanının etkinliği artar.

- Maliye politikası çarpanının değeri, dikkate alınan verginin ya da kamu harcamasının türüne göre farklılık gösterebilir.

- Cari işlemler dengesi fazla veren, esnek döviz kuru uygulayan göreli daha dışa açık ekonomiye ${ }^{42}$ sahip ülkelerde maliye politikası çarpanının değeri göreli olarak daha düşüktür. ${ }^{43}$

42 Burada dışa açık ekonomiden kasıt, uluslararası ticarete bağlı ülkelerdir. Buna göre, dış ticaret hacminin [İhracat + İthalat] GSYiH'ye oranı \%60'ın üzerinde olan ülkeler dışa açık; altında olanlar ise dışa kapalı ekonomi olarak kabul edilmektedir. Bkz. Ilzetzki, Mendoza \& Vegh (2013).

43 Aslinda bu bulgu dışa açık ekonomiye ilişkin Mundell-Fleming Modeli'ne de uygundur. Bu modele göre sermaye hareketlerinin serbest olduğu ve esnek kur sisteminin uygulandığı dışa açık bir ekonomide maliye politikası etkin değildir; ancak, para politikası etkindir. 
- Esnek kur sistemine sahip ülkelerde maliye politikası çarpanın değeri sıfıra yaklaşırken, esnek olmayan kur sisteminin geçerli olduğu ülkelerde maliye politikası çarpanının değeri hem pozitif, hem de birden büyük olmaktadır.

- Fiyatlar daha esnek iken uygulanacak gevşek bir para politikası maliye politikası çarpanının değerini arttırır.

- Hangi maliye politikası enstrümanının kullanıldığı da maliye politikası çarpanı açısından önemlidir. Vergi indirimlerinin neden olduğu açığın maliye politikası çarpanı üzerindeki etkisi harcamalardaki artışın neden olduğu açığa göre daha fazladır.

- Genel olarak kamu borcunun yüksek olması, maliye politikası çarpanının değerini düşürmektedir. Hatta merkezi hükümet borcunun GSYIH'ye oranı \%60'ın üzerinde olan bazı ülkelerde çarpanın değeri negatif olmaktadır.

- Ülkelerin gelişmişlik düzeyi, maliye politikası çarpanının değerini etkiler. Genel olarak gelişmişlik düzeyi düşük olan ülkelerde maliye politikası çarpanının değeri de düşüktür.

\section{Sonuç ve İleriye Yönelik Bazı Politika Çıkarımları}

Son krizle beraber maliye politikasına geri dönüş bir zorunluluğun sonucudur. O zorunluluk da para politikasının nominal faiz oranlarının sıfıra dayandığı bir noktada ekonomik faaliyetleri etkilemedeki işlevselliğini kaybetmesi nedeniyle ortaya çıkan seçeneksizliktir. 2007'nin ikinci yarısında ABD'de başlayan finansal krizle mücadelede para politikası arzulanan sonucu vermeyince, zoraki olarak maliye politikası gündeme geldi. Kriz derinleşirken, nominal faiz oranlarının sıfıra dayandığı, para politikası ile faizleri, faizlerle de ekonomik faaliyetleri etkileme olanağının kalmadığı bir noktada, ekonomik krizlerin üstesinden gelmede bir imdatçı olarak maliye politikası devreye girdi.

Maliye politikasının, özellikle resesyon ve durgunluk dönemlerinde toplam talebi ve dolayısıyla iktisadi faaliyetleri etkilemede para politikasına göre daha etkin iktisat politikası aracı olduğu son krizle birlikte bir kez daha görüldü. Ancak bu etkinin yönü ve büyüklüğünün hala tartışmalı bir konu olduğu da aşikârdır. Bunun yanında, maliye politikasının, hantal bir politika olduğundan şüphe yoktur. Ancak maliye politikası diğer iktisat politikası aracı olan para politikasına göre daha net ve kesin sonuçlar ortaya koymaktadır. Öte yandan maliye politikası, yapısı gereği popülist amaçlarla kullanıma yatkın bir politikadır. Siyasi duyarlılı̆̆ politikanın dizaynı ve uygulanması iş başındaki hükümetlerin kontrolü ve uygulaması altındadır. Maliye politikasının bir diğer açmazı, gecikmeler sorunudur. İktisadi sorunun teşhisi ile soruna karşı çözüm üretilmesi, üretilen çözüm ile müdahale kararı alınması, alınan karar ile uygulama ve sonuç alınması uzunca bir prosedüre ve zamana ihtiyaç duyar. 
Tüm bu handikapları da dikkate alarak, maliye politikasına ilişkin aşağıdaki çıkarımları yapabilir ve ileriye yönelik politika önerilerinde bulunabiliriz:

- Günümüzün küreselleşen, sermaye hareketleri serbestleşen ve finansal piyasaları birbirine entegre olan dünyasında maliye politikası, mutlaka para politikasıyla ve hatta finansal politikalarla eşgüdümlü olarak uygulanmalıdır. Zira bu eşgüdümün ne denli gerekli olduğu son yaşanan kriz ile de teyit edilmiştir. Bunun için de söz konusu politikalar arasında koordinasyona ihtiyaç vardır. Maliye politikasının ne ölçüde etkili olacağı ve başarılı sonuçlar ortaya koyacağı, bu koordinasyonun sürekliliğine ve kalitesine bağlıdır. Koordinasyonsuzluk, sorunu ortadan kaldırmak bir yana, daha da içinden çıkılmaz hale getirecektir.

- Maliye politikasının otomatik stabilizatörlük işlevi, kamu kesiminin büyüklüğü ve ekonominin gelişmişlik düzeyi ile yakından ilişkilidir. Kamu kesimi büyüdükçe, otomatik stabilizatörlerin etkinliği göreli olarak artmaktadır. Otomatik stabilizatörler refah devleti uygulamalarının geçerli olduğu harcamaların yüksek marjinal vergi oranları ile finanse edildiği ülkelerde daha etkindir (Hemming, 2013). ${ }^{44}$

- Gelişmiş ülkelerde otomatik stabilizatörlerin etkinliği, gelişmekte olan ülkelere göre daha fazladır. Ancak burada önemle belirtelim ki, otomatik stabilizatörlerle ilgili olarak daha önemlisi husus, bunların nasıl dizayn edildiğidir.

- Ekonominin olağan dönemlerinde otomatik stabilizatörlerin işlevselliği yüksek olsa da, ekonomide ciddi dalgalanmaların olduğu dönemlerde otomatik stabilizatörler konjonktürel dalgalanmaların dizginlenmesinde oldukça yetersiz kalmaktadır. O nedenle, krizlerle mücadelede ihtiyari-aktif maliye politikasının devreye sokulması bir zorunluluk olarak karşımıza çıkmaktadır.

- Ülkeden ülkeye farklılık gösterebilmesine karşın, otomatik stabilizatörler ancak küçük çaplı ekonomik dalgalanmaların minimize edilmesinde etkili olabilir. O nedenle büyük çaplı ekonomik dalgalanmaların kontrolünde ihtiyari-aktif maliye politikasına ihtiyaç olduğu ülke tecrübeleri ile sabittir.

- İhtiyari-aktif maliye politikası uygulamasındaki uzun süreli gecikmeler, özellikle resesyon gibi kısa dönemli durgunlukla mücadelede bu politikasının etkinliğini önemli ölçüde azaltmaktadır. $\mathrm{Bu}$ ve benzeri durumlarda otomatik stabilizatörler önem kazanmaktadır.

44 İsveç, Danimarka, Norveç gibi İskandinav ülkeleri bunun tipik örnekleridir. 
- Krizlerle mücadelede ihtiyari-aktif maliye politikasının zamanlaması, dozu ve araçlarının seçimi de bir o kadar önemlidir. O nedenle bu politika mutlaka uygun zamanda, uygun dozda ve uygun araçlarla uygulamaya konulmalıdır. Örneğin, ihtiyari-aktif maliye politikasının zamanlamasının iyi ayarlanamaması durumunda istenilen sonuçlara ulaşılması gereksiz yere uzayabileceği gibi, güçleşebilir ya da mevcut ekonomik soruna çare olmayabilir ve hatta beklenenin aksi yönde sonuçlar ortaya çıarabilir. Bu da ancak ihtiyari-aktif maliye politikasının gerek dizaynında gerekse uygulanmasında proaktif bir politika yaklaşımının izlenmesi, ulusal ve uluslararası düzeyde ekonomik ve siyasi gelişmelerin an be an izlenmesi ve kötü gidişatın sinyallerinin alındığı andan itibaren teyakkuza geçilmesi ile mümkündür.

- Yine ülke tecrübeleriyle sabittir ki, ihtiyari-aktif maliye politikası kötüye kullanıma açık bir politikadır. O nedenle maliye politikasının politik müdahalelerden arındırılması kendisinden beklenilen başarının sağlanmasında hayati önem taşımaktadır. Bu açıdan kötü kullanıma açık esnek bir maliye politikasından daha ziyade, kurallı bir maliye politikası daha rasyonel bir tercih olabilir.

- Günümüz ekonomilerinin en önemli olgularından biri beklentiler ve bu beklentilerin iyi yönetilmesidir. Çünkü beklentiler günümüz ekonomileri için bir hayli önemli bir husustur. Yalnızca hâlihazırdaki vergiler ve kamu harcamaları değil; gelecekteki mali aktivitelere ilişkin beklentiler de ekonomiyi etkiler. Maliye politikasında yapılacak bir değişikliğin etkisi, büyük ölçüde hanehalkının ve iktisadi ajanların beklentilerine ve ekonomik kararlarında dikkate aldıkları zamana bağlı olmaktadır.

- Uygulanan maliye politikasının mali sürdürülebilirliği nasıl etkileyeceği, makroekonomik etkilerinin neler olacağı dikkate alınmalıdır. Bu durum, maliye politikalarının kendi içinde ve geleceğe yönelik makroekonomik hedeflerle uyumlu kalmasına bağlıdır.

- Maliye politikası çarpanının büyüklügü, maliye politikası uygulandığı andaki konjonktürel dalgalanmaların aşamasına [tepe, daralma, dip, genişleme] bağlıdır. Çarpanın değeri, konjonktürel dalgalanmanın evresine göre farklılık gösterir. O nedenle ekonominin içinde bulunduğu konjonktür maliye politikasının etkinliği bakımından dikkate alınması gereken bir husustur. Tabi bunda para politikasının rolünü de göz ardı etmemek gerekir. Özellikle ekonominin daralma ve dip noktalarında uygun bir para 
politikasıyla desteklenen maliye politikasının başarı şansı artacak ve maliye politikası çarpanının değeri daha da artacaktır. ${ }^{45}$

- Hemen hemen bütün ampirik çalışmalar göstermektedir ki, Keynes’in söylemlerini teyit edercesine kısa dönem kamu harcamaları çarpanının değeri 1'den büyüktür. Ancak yine de belirtelim ki, bu hususta temkinli olmakta yarar vardır. Genişletici maliye politikasının özellikle de vergi indirimi kaynaklı olanın ekonominin talep cephesinden ziyade arz cephesini etkileyeceği yönünde de yaygın bir kanı vardır. Bu kanı son krizle beraber maliye politikası ön plana çıkmasına rağmen devam etmektedir. Dahası, bu yönde görüş beyan edenler vergilerin kamu harcamalarına göre ekonomi üzerinde daha güçlü bir etkiye sahip olduğu ve bu bağlamda mali paketlerin gelir ve kurumlar vergisi indirimli olması gerektiğini savunmaktadırlar. ${ }^{46}$

Çalışmanın başlangıcında da değindiğimiz gibi, her krizin bir öğretici yanı bulunmaktadır. Daha öncekilerden farklı olarak bu krizin öğretici yanı, ön yargılı ve saplantılı olmamaktır. Durum ve koşullara göre, en ideal politika aracı ne ise onu devreye sokmaktır. Bir diğer önemli husus da, ülkeler arasında genelleme yapmaktan mümkün mertebe kaçınmak ve her ülkeyi kendi özelinde değerlendirmektir.

\section{Kaynakça}

Afonso, A. (2001), "Non-Keynesian Effects of Fiscal Policy in the EU-15, University of Lisbon", Department of Economics from ISEG - School of Economics and Management, Department of Economics, Working Papers, 2001/07, 1-47.

Aktan, C.C. \& H. Şen (2001), "Ekonomik Kriz: Nedenler ve Çözüm Önerileri”, Yeni Türkiye Dergisi, Ekonomik Kriz Özel Sayıs1, 42, Kasım-Aralık 2001, 1225-1230.

Alcidi, C. \& D. Gros (2011), "Great Recession versus Great Depression: Monetary, Fiscal and Banking Policies”, Journal of Economic Studies, 38(6), 673-690.

Alesina, A. (2012), "Fiscal Policy after the Great Recession", Atlantic Economic Journal, 40, 429435.

Alesina, A. \& S. Ardagna (2010), "Large Changes in Fiscal Policy: Taxes versus Spending", Tax Policy and the Economy, 24(1), 35-68.

Anderson, C.J. (1944), “The Development of the Pump-Priming Theory”, Journal of Political Economy, 52(2), 144-159.

Arestis, P. (2011), "Fiscal Policy is Still an Effective Instrument of Macroeconomic Policy", Panoeconomicus, 2, 143-156.

45 Para politikasının maliye politikası şoklarına verdiği tepkileri dikkate alan ve ona göre belirlenen çarpanı Delong \& Summers (2012), "politika bağlantılı mali çarpan” olarak adlandırmaktadır.

46 Son krizle uygulamaya konulan maliye politikası paketleri ve Obama Hükümeti'nin maliye politikası çarpanı odaklı mali paketlerinin eleştirisi için bkz. Mankiw (2010). 
Arestis, P. (2012a), "Fiscal Policy: A Strong Macroeconomic Role", Review of Keynesian Economics, Inaugural Issue, 93-108.

Arestis, P. (2012b), "Fiscal Policy: Time for the Renaissance of Keynesianism", in G. Chaloupek \& M. Marterbauer (eds.), 75 Jahre General Theory, Employment, Interest and Money, Wirtschaft-swissenschaftliache Tagungen der AK-Wien, Band 17.

Arestis P. \& M. Sawyer (2010), “The Return of Fiscal Policy”, Journal of Post Keynesian Economics, 32(3), 327-346.

Auerbach, A.J. (2012), “The Fall and Rise of Keynesian Fiscal Policy”, Asian Economic Policy Review, 7, 157-175.

Auerbach, A.J. \& W.G. Gale \& B.H. Harris (2010), “Activist Fiscal Policy”, Journal of Economic Perspectives, 24(4), 141-164.

Auerbach, A. \& Y. Gorodnichenko (2012), "Measuring the Output Responses to Fiscal Policy", American Economic Journal: Economic Policy, 4(2), 1-27.

Barro, R.J. \& C.J. Redlick (2011), "Macroeconomic Effects from Government Purchases and Taxes", Quarterly Journal of Economics,126, 51-102.

Bernanke, B. (2002), “Deflation: Making Sure “It” Doesn’t Happen Here”, Speech Before the National Economist Club, <www.federalreserve.gov/boarddocs/speeches/2002/20021121/default.htm>, 10.10.2014.

Blanchard, O. \& D. Giovanni \& M. Paolo (2010), "Rethinking Macroeconomic Policy", Journal of Money, Credit and Banking, 42(1), 199-215.

Blinder, A.S. (1988), “The Fall and Rise of Keynesian Economics”, Economic Record, 64(4), 278294.

Briotti, M.G. (2005), "Economic Reactions to Public Finance Consolidation: A Survey of the Literature", European Central Bank Occasional Paper Series, 38, 1-29.

Claessens, S. \& M.A. Kose (2009), "What is a Recession", Finance \& Development, March 2009, 46 (1), 152-53.

Claessens, S. \& M.A. Kose \& M. Terrones (2008), "What Happens During Recessions, Crunches, and Busts?”, IMF Working Paper, No: 08/274 International Monetary Fund: Washington.

Coenen, G. \& R. Straub \& M. Trabandt (2012), "Fiscal policy and the Great Recession in the Euro Area”, European Central Bank, ECB Working Paper, 1429, March 2012, 1-11.

DeLong, J.B. \& L.H. Summers (2012), "Fiscal Policy in a Depressed Economy”, Brookings Papers on Economic Activity, 44(1), 233-297.

De Mello, L. (2013), "What Can Fiscal Policy Do in the Current Recession? A Review of Recent Literature and Policy Options", Hacienda Pública Española / Review of Public Economics, 204(1), 113-139.

Dullien, S. (2012), "Is New Always Better than Old? On the Treatment of Fiscal Policy in Keynesian Models", Review of Keynesian Economics, Inaugural Issue, Autumn 2012, 5-23.

Feldstein, M. (2009), "Rethinking the Role of Fiscal Policy", American Economic Review, 99(2), 556-559.

Ferreiro, J. \& C. Gomez \& F. Serrano (2013), "Mistakes in the Fiscal Policy in Spain before the Crisis", Panoeconomicus, 5, 577-592. 
Fishback, P.V. (2008), New Deal, in The New Palgrave Dictionary of Economics, Second Edition, Edited by Steven N. Durlauf \& Lawrance E. Blume, Palgrave Macmillan.

Giavazzi, F. \& M. Pagano (1990), "Can Severe Fiscal Contractions be Expansionary? Tales of Two Small European Countries", NBER Macroeconomic Annual, 5, 75-110.

Giavazzi, F. \& M. Pagano (1996), "Non-Keynesian Effects of Fiscal Policy Changes: International Evidence and the Swedish Experience", Swedish Economic Policy Review, 67-103.

Giavazzi, F. \& T. Jappelli \& M. Pagano (2000), "Searching for Non-linear Effects of Fiscal Policy: Evidence from Industrial and Developing Countries", European Economic Review, 44, 1259-1289.

Gorton, G.B. (2008), “The Panic of 2007, National Bureau of Economic Research", NBER Working Paper, 14358, 1-93.

Hemming, R. (2013), “The Macroeconomic Framework for Managing Public Finances”, in: Richard Allen \& Richard Hemming \& Barry H. Potter (Eds.), The International Handbook of Public Financial Management, Palgrave-Macmillan: London, 17-37.

Hemming, R. \& M. Kell \& S. Mahfouz (2002), "The Effectiveness of Fiscal Policy in Stimulating Economic Activity - A Review of the Literature", IMF Working Paper, No: WP/02/208, The International Monetary Fund: Washington DC.

IMF (2008), "Fiscal Policy as a Countercyclical Tool", in: World Economic Outlook, Chapter 5, October 2008, International Monetary Fund: Washington DC.

Ilzetzki, E. \& E.G. Mendoza \& C.A. Vegh (2013), “How Big (Small?) are Fiscal Multipliers?”, Journal of Monetary Economics, 60(2), 239-254.

Issing, O. (2010), “Is Monetarism Dead?”, The International Economy, The Magazine of International Economic Policy, Spring 2010, 35-37.

Jha, S. \& S.K. Mallick \& D. Park \& P.F. Quising (2014), "Effectiveness of Countercyclical Fiscal Policy: Evidence from Developing Asia", Journal of Macroeconomics, 40, 82-98.

Jordan, T.J. (2012), "Some Lessons for Monetary Policy from the Recent Financial Crisis", International Journal of Central Banking, 8(1), 289-292.

Kindleberger, C.P. (2007), Cinnet, Panik ve Çöküş-Mali Krizler Tarihi, Çeviren: Halil Tunalı, İstanbul Bilgi Üniversitesi Yayınları, 4. Baskı, İstanbul.

Kopcke, R.W. \& G.M.B. Tootell \& R.K. Triest (2006), "Introduction: The Macroeconomics of Fiscal Policy", in: Richard W. Kopcke \& Geoffrey MB Tootell \& Robert K Triest (Eds.), The Macroeconomics of Fiscal Policy, The MIT Press: Cambridge, London, 1-20.

Lerner, A.P. (1941), “The Economic Steering Wheel”, University Review, June, 2-8.

Lerner, A.P. (1943), "Functional Finance and the Federal Debt”, Social Research, 10(1), 38-51.

Mankiw, N.G. (2010), "Questions about Fiscal Policy: Implications from the Financial Crisis of 2008-2009”, Federal Reserve Bank of St. Louis Review, May/June 2010, 93(3), 177-183.

Musgrave, R.A. (1959), The Theory of Public Finance: A Study in Public Economy, McGraw-Hill: New York.

Pelinescu, E. \& P. Caraiani (2010), "Fiscal Policy in the Context of the Economic Crisis", Romanian Journal of Fiscal Policy, 1(1), 1-21.

Romer, C.D. (2003), "Great Depresion”, in: Encyclepedia Britannica, $<$ http://eml.berkeley.edu/ cromer/great_depression.pdf>, 07.06.2014. 
Romer, C.D. (2011), What Do We Know About the Effects of Fiscal Policy? Separating Evidence from Ideology, Invited Lectures, Hamilton College, November 7, 2011.

Romer, C.D. \& D.H. Romer (2010), "The Macroeconomic Effects of Tax Changes: Estimates Based on a New Measure of Fiscal Shocks", American Economic Review, 100(3), 763-801.

Strauss-Khan, D. (2011), Global Challenges, Global Solutions, An Address at George Washington University, Washington, April 4, 2011, <http://www.imf.org/external/np/speeches/2011/040411.htm>, 20.11.2014.

Spilimbergo, A. \& S. Symansky \& O. Blanchard \& C. Cottarelli (2009), "Fiscal Policy for the Crisis”, IMF Staff Position Note, December 29, 2008, SPN/08/01, 1-38.

Şen, H. \& A. Çalışkan (2009), "Mortgage Kaynaklı Küresel Kriz ve Türkiye Ekonomisine Muhtemel Yansımaları”, Kamu'da Sosyal Politika Dergisi, Sayı: 8(1), 11-18.

Şen, H. \& İ. Sağbaş \& A. Keskin (2007), Bütçe Açıkları ve Açık Finansman Politikası Teori ve Türkiye Uygulaması, Orion Kitabevi: Ankara.

Şen, H. \& A. Kaya (2013), "The Role of Taxes as an Automatic Stabilizer: Evidence from Turkey", Economic Analysis and Policy, 43(3), 303-313.

Şen, H. \& A. Kaya (2014), "Crowding-Out or Crowding-In? Analyzing the Effects of Government Spending on Private Investment in Turkey”, Panoeconomicus, 61(6), 631-651.

Tanzi, V. (2006), "Fiscal Policy: When Theory Collides with Reality, Centre for European Policy Studies", Ceps Working Document, 246, June 2006, 1-18.

Tcherneva, P.R. (2011), "Fiscal Policy Effectiveness: Lessons from the Great Recession", Levy Economics Institute of Bard College, Working Paper, 649, 1-26.

Temin, P. (2008), Great Depression, in The New Palgrave Dictionary of Economics, Second Edition, Ed. by Steven N. Durlauf and Lawrence E. Blume, 5493-5501.

Tokucu, E. \& E. Sarıdoğan (2010), "Kriz ve Maliye Politikalarının Geri Dönüşü CCerçevesinde Fonksiyonel Maliye: Bir Literatür Taraması”, Marmara Üniversitesi İïBF Dergisi, XXIX(II), 77-98.

Wheelock, D.C. (1992), "Monetary Policy in the Great Depression: What the Fed Did, and Why", Federal Reserve Bank of St. Louis Review, March/April 1992, 74(2), 3-28.

White, E. N. (1990), “The Stock Market Boom and Crash of 1929 Revisited”, Journal of Economic Perspectives, 4(2), 67-83. 
Hüseyin ŞEN \& Ayşe KAYA 